\title{
THE FINAL PASSAGE
}

The final journey for slaves from Cartagena to Lima was characterised by numerous variations in their diet and living conditions. The foods fed to slaves differed markedly on different stretches of the journey reflecting local environmental conditions, traditional agricultural practices, as well as the availability of labour, the demand for provisions and the spread of European and African crops and livestock. While these affected the price of foods and hence those that were fed to slaves, slave traders did not always select the cheapest foods available since inadequate diets would lead to poor health, increase mortality and reduce profits. On the journey from Cartagena in 1633 the cost of maintenance for one slave, which included food, clothing, lodging and medical treatment from the time of purchase in Cartagena to arrival in Lima, was calculated at about 17 pesos 4 reals. ${ }^{1}$ (Table 6.1). This was about one-third of the total cost of transhipment, which averaged between 50 and 60 pesos per slave; transport and taxes accounted for the rest. About this time slaves were being purchased in Cartagena for an average of between 270 and 310 pesos and could be sold in Lima for between 580 or 600 pesos. Since a good profit could be made on each slave, it was in the slave traders' interest to maintain the health of slaves and not economise excessively on expenditure on food. Slave traders therefore continued to purchase foods, such as pork and chickens that they regarded as healthier, even though they were more expensive, and also to provide them with foods in a form with which they were familiar. To put these changes in context and explore the conditions experienced by slaves more generally, the analysis will follow their journey through Panama to the coast of Peru and finally to Lima.

${ }^{1}$ AGNL SO CO Ca 18 doc 197 p. 715 Upper Guinea accounts 1613-1618; AGNL SO CO ca. 20 doc 201 Money owed by Juan de la Cueva for the purchase and upkeep of slaves 1633; AGNL SO CO ca. 20 doc 201 Slaves purchased (August-December, 1629). See also: AGNL SO CO Ca 18 doc 197 p. 210 expenses generated by 4-5 slaves belonging to Antonio Rodríguez de Acosta (1622) and p. 214 Expenses generated by 4 slaves belonging to Diego de Ovalle [1623].

(C) LINDA A. NEWSON AND SUSIE MINCHIN, 2007| DOI 10.1163/9789004156791_008

This is an open access chapter distributed under the terms of the CC BY-NC-ND 4.o license. 
Table 6.1. Costs Incurred in the Transport of Slaves from Cartagena to Lima in 1633

\begin{tabular}{|c|c|c|}
\hline & Cost & Percent \\
\hline Transport from Cartagena to Portobello & 20 reals & 4.4 \\
\hline Food and supplies from Cartagena to Portobello & 4 pesos & 7.0 \\
\hline Entry tax in Portobello & $\begin{array}{l}2 \text { pesos males, } \\
1 \text { peso females (pesos } \\
\text { of } 9 \text { reals) }\end{array}$ & 4.0 \\
\hline $\begin{array}{l}\text { Food and other expenses in Portobello and } \\
\text { on the journey across the isthmus, including } \\
\text { the hire of mules }\end{array}$ & 2 pesos & 3.5 \\
\hline New entry tax in Panama & 12 reals & 2.6 \\
\hline Valuation of slaves in Panama & 4 reals & 0.9 \\
\hline Blankets for the slaves in Panama & 12 reals & 2.6 \\
\hline $\begin{array}{l}\text { Expenses in Panama and Paita, and supplies } \\
\text { for the journey to Lima (includes food and } \\
\text { medical treatment) }\end{array}$ & 10 pesos & 17.6 \\
\hline Transport to Lima & 13 pesos ensayados & 37.9 \\
\hline Royal taxes & $\begin{array}{l}3 \text { pesos } 4 \text { tomines } \\
\text { ensayados }\end{array}$ & 10.1 \\
\hline Local tax (cimarrones) & 25 reals & 5.5 \\
\hline Customs tax & 9 reals & 2.0 \\
\hline Valuation in Lima & $\begin{array}{l}1 \text { peso } \\
56 \text { pesos } 6 \text { reals }\end{array}$ & $\begin{array}{r}1.8 \\
99.9\end{array}$ \\
\hline
\end{tabular}

Source: AGNL SO CO Ca 20 doc 201 Money owed by Juan de la Cueva for the purchase and transport of eighteen Angolan slaves 1633.

The percentage of expenditure is calculated on the taxes paid for male slaves.

\section{The Fourney to Panama}

The journey from Cartagena to Portobello on the Caribbean coast of Panama took nine to ten days. ${ }^{2}$ Due to its vulnerability to pirate attack and its reputation for being unhealthy, ${ }^{3}$ Portobello was only occupied for brief periods of the year when the Spanish fleets arrived to exchange European manufactures for Peruvian silver. The fair generally lasted fifteen days and was held in late July and early

2 Bowser, African Slave, 63.

3 There are numerous accounts of the unhealthiness of Portobello from the time it was founded. See for example, AGI Panamá 32 N26 La ciudad de San Phelipe de Puertobelo 1603, Panamá 32 N175 Tesorero Baltasar Pérez Bernal 4 Nov. 1603, Panamá 45 N49 Alcalde Mayor, Don Bernardo de Vargas 3 Jun. 1603, Panamá 64B N4 doc 1 Información de los méritos. Don Gonzalo Mendina Lisón 1629. 


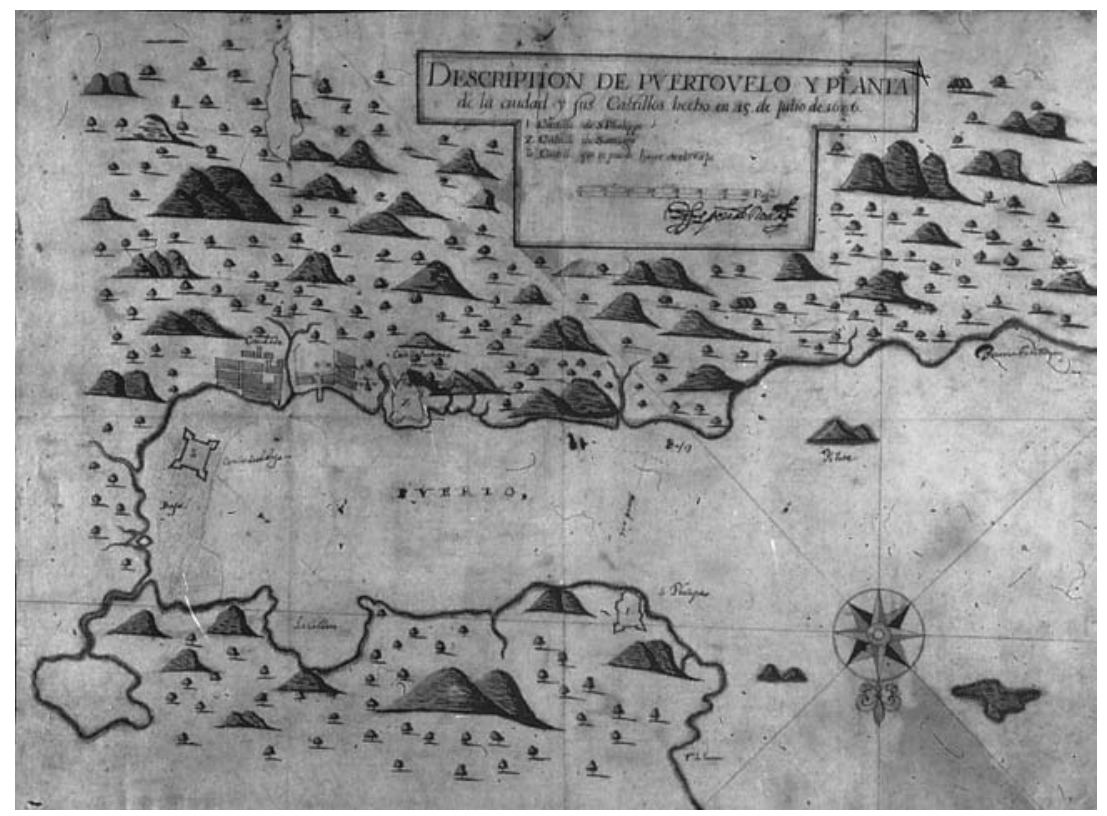

Figure 4. Portobello in 1626. (Courtesy Spain. Ministerio de Cultura. Archivo General de Indias Mapas y Planos Panamá 42 Descripción de Puertovelo y Planta de la ciudad y sus castillos in 1626 by Cristóbal de Roda).

August. ${ }^{4}$ Although Portobello had been founded in 1597 with thirty wealthy vecinos, ${ }^{5}$ by 1618 many houses had been abandoned and only twelve poor vecinos were living there. ${ }^{6}$ The city's small resident population of Spaniards, free Blacks and Mulattoes, ${ }^{7}$ meant that few agricultural activities developed in its hinterland, where in 1607 it

${ }^{4}$ A.C. Loosely, "The Puerto Belo Fairs," Hispanic American Historical Review 13 (1933): 318, 320-21; Thomas Gage, Travels in the New World, edited by J. Eric S. Thompson (Norman: University of Oklahoma Press, 1958), 329; Lawrence A. Clayton, "Trade and Navigation in the Seventeenth-Century Viceroyalty of Peru," Fournal of Latin American Studies 7(1)(1975): 2-3).

${ }^{5}$ Within ten years of being founded it had only 50 wooden houses roofed with thatch, plus another 34 houses in four suburbs inhabited by free Black and poor Spaniards (CDI 9: 109-10 Descripción corográfica 1607).

${ }^{6}$ AGI Panamá 63A N 15 doc 1 Ciudad de Puerto Velo 1618. This document includes a padrón of the residents of Portobello and those who had houses there but no longer lived in the city. See also AGI Panamá 47 N3 Sargento Mayor Don Francisco de Narváez 24 Apr. 1620.

7 Vázquez de Espinosa, Compendio, 212. 


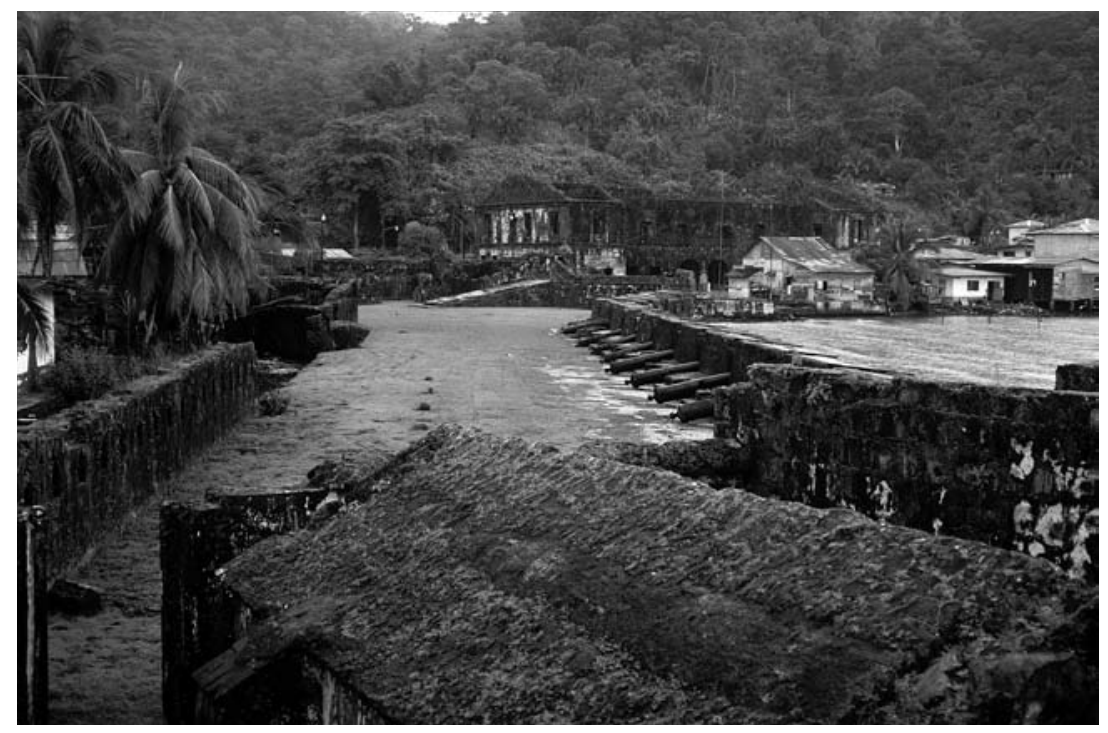

Figure 5. Portobello. Colonial Warehouses in the Background (Author).

was said there were only three chacras raising plantains, fruit and some chickens. ${ }^{8}$ Meat and maize therefore had to be brought in; some came from estates around Panamá, ${ }^{9}$ but it was often cheaper to import food from Cartagena and Tolú. Due to Portobello's reliance on food imports and the enormous demand for provisions, food prices were exceptionally high, particularly during the few weeks of the fair, when apart from the influx of residents from Panamá the fleet might bring 4,000 to 5,000 sailors and soldiers. ${ }^{10}$

Manuel Bautista Pérez's slaves did not arrive in Portobello at the time of the fair, but between October or December and most commonly in November. Because of the high cost of provisions and its unhealthy reputation, most merchants and travellers stayed in Portobello

${ }^{8}$ CDI 9: 115 Descripción corográfica 1607.

9 The name Panamá is used to refer to the city of Panama and Panama to the region.

${ }_{10}$ Visiting the Portobello fair in 1637 Thomas Gage was outraged that a chicken cost twelve reals whereas he normally paid only one real, and that a pound of beef cost two reals when elsewhere a half a real could buy thirteen pounds (Gage, Travels, 330). Evidence from the account books suggests that these figures were exaggerated or quite exceptional, though the general observation that prices were very high was valid. 
for as short a time as possible. Most consignments of slaves remained there for only three or four days, sufficient for the slave traders to despatch the paper work, pay the entrada tax,${ }^{11}$ and assemble the mules and provisions for the journey across the isthmus. As was common practice, these bureaucratic procedures involved a range of gifts and bribes. ${ }^{12}$ During this time the slaves were lodged in houses rented at between 25 and 35 pesos.

In the early colonial period the journey across the isthmus from Portobello took one of two routes. ${ }^{13}$ First there was an eighteenleague overland trail through the mountains. The initial stretch of this trail was steep as it crossed the Capira or Santa Clara mountains where it followed a tortuous path that continued down the Boquerón Valley. Here the landscape was rugged with steep slopes, deep ravines and fast flowing rivers. The trail was sometimes only a few feet wide and flanked by drops of 120 to 150 metres. After the junction of the Boquerón and Pequeñí Rivers the going became easier until it reached the River Chagres, which had to be crossed before proceeding to Panamá. The journey overland from Portobello to Panamá normally took four days.

Alternatively, the greater part of the journey could be undertaken by the Chagres River, which originated three leagues from Panamá and flowed north to the Caribbean Coast entering the sea about eight leagues west of Portobello. The reverse route from Portobello involved a short passage by sea to the mouth of the Chagres and then transference to small boats or barges propelled by slaves using long poles, which could navigate the shallow river to Venta de Cruces. Here passengers and cargoes were unloaded to continue the remaining five leagues of the journey overland by mule. The total journey took between one and two weeks, depending on the river level and currents. ${ }^{14}$ The river was highest in November and December and

11 This tax was two pesos of nine reals for each male and one peso of nine reals for each female (see AGNL SO CO Ca 20 doc 201 Money owed by Juan de la Cueva, for the purchase and upkeep of slaves (1633) and Journal for 1634).

12 Manuel Bautista Pérez's accounts indicate that he might pay up to 150 pesos.

${ }_{13}$ Descripción del virreinato del Perú, 117-120; Roland D. Hussey, "Spanish Colonial Trails in Panama," Revista de Historia de América 6 (1939): 58-64; Christopher Ward, Imperial Panama: Commerce and Conflict in Isthmian America, 1550-1800 (Albuquerque: University of New Mexico Press, 1993), 56-60; María Carmen del Mena García, La ciudad en un cruce de caminos: Panamá y sus orígines urbanos (Seville: Escuela de Estudios Hispanoamericanos, 1992), 73-79.

${ }_{14}$ This journey upriver by Francesco Carletti in 1594 took 19 days (Carletti, Voyage, 29). 


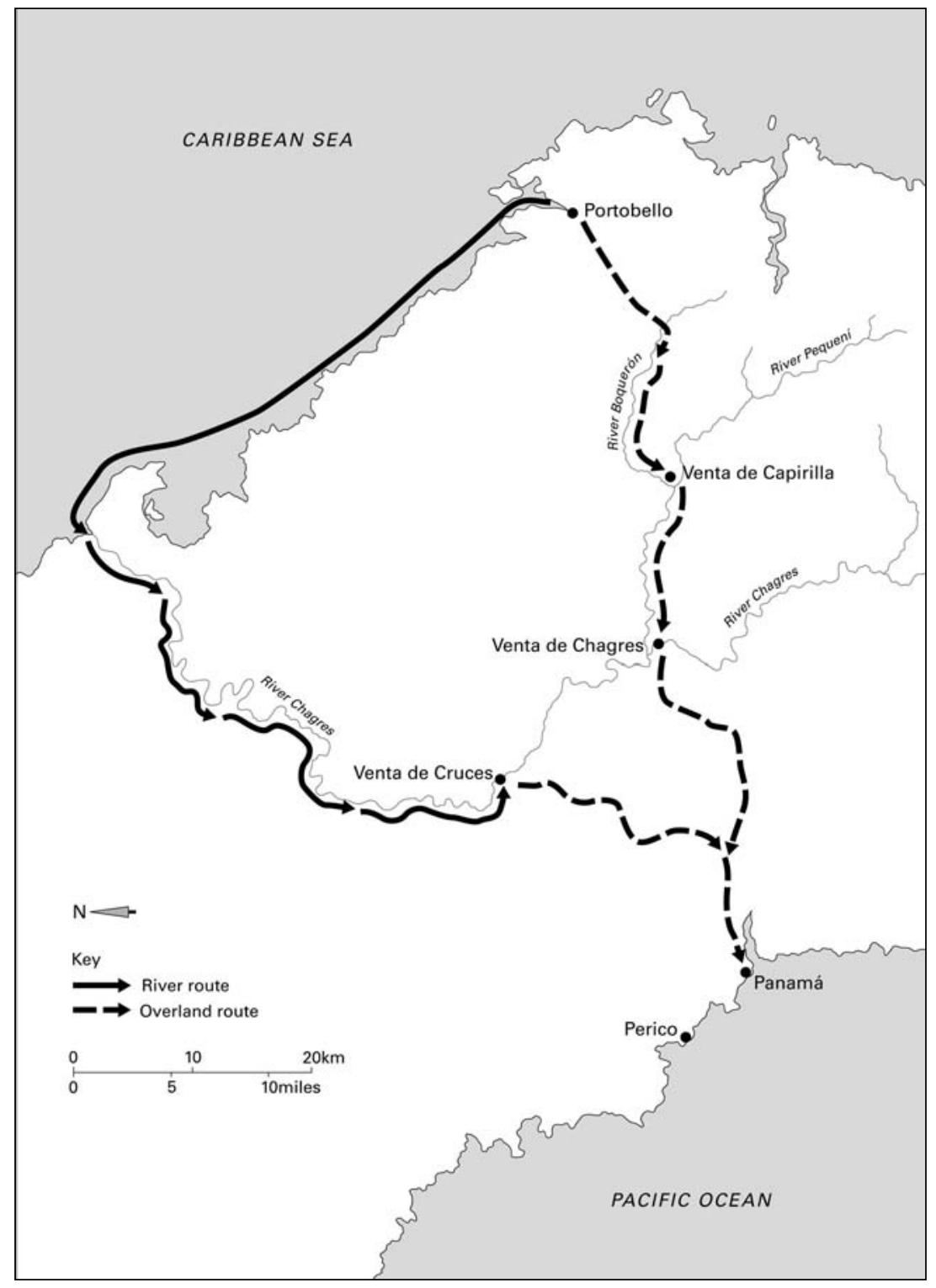

Map 6. Routes Across the Panamanian Isthmus in the Early Seventeenth Century. 
could not be used in the dry season from January to April..$^{15}$ When Thomas Gage travelled this route in 1637 the difficulties of navigating in low water meant that the normally quicker journey downriver from Venta de Cruces took twelve days. ${ }^{16}$ Nevertheless, the river route was two to three times cheaper and was generally preferred for bulk transport, even though it was vulnerable to attack by foreign corsairs, particularly on the short stretch of the journey on the open water between the mouth of the Chagres River and Portobello. ${ }^{17}$

From the account books it appears that Manuel Bautista Pérez's slaves took both routes. Most slaves crossed the isthmus on foot, with the river route being used primarily for weak or sick slaves, for whom boards were provided for sleeping on. One disadvantage of the overland route was the greater ease with which slaves could flee. Hence significant sums were expended in the supervision of the slaves in Portobello and in escorting them on the journey; it is doubtful that they were chained together for on most journeys several slaves fled, some of whom were never found. ${ }^{18}$ Perhaps to minimise fugitivism as well as undertake general supervisory duties, it was common practice to select one of the slaves as 'capitán'. ${ }^{19}$ The slaves were accompanied by a number of mules, which carried provisions and merchandise destined for Peru. The main supplier of mules to the slave traders at this time was Pedro Cano who hired them out for the journey across the isthmus at 25 to 30 pesos apiece. ${ }^{20}$

${ }^{15}$ López de Velasco, Geografia, 178; Descripción del virreinato del Perú, 119.

${ }^{16}$ Gage, Travels, 328. Because the journey up river took longer it was more expensive than downriver (Alfredo Castillero Calvo, La ruta transístmica y las comunicaciones maritimas hispanas, siglos XVI a XIX (Panama: Ediciones Nari, 1984, 19).

${ }_{17}$ Castillero Calvo, "Ruta transístmica", 10; Ward, Imperial Panama, 57-58.

${ }^{18}$ In 163394 pesos were spent in trying to find several slaves who fled, but in the end two male Angolan slaves were never found (AGNL SO carpeta 20 doc 201 Memoria de los negros que el Capitán Sebastián Duarte compró el año pasado de 1633).

19 AGNL Real Audiencia Causas Civiles Leg. 45 Cuad. 171 Autos seguidos por Don Pedro Gómez de Mora, barbero, contra Don Francisco Guisado y otros Paita, 4.4.1618; Bowser, African Slave, 63-64.

${ }^{20}$ Ward, Imperial Panama, 64; Vázquez de Espinosa, Compendio, 212. Alfredo Castillero Calvo, has undertaken a detailed analysis of the cost of mule transport across the Panamanian isthmus revealing the journey to be the most costly in Spanish America (Economía terciaria y sociedad: Panamá siglos XVI y XVII (Panama: Instituto Nacional de Cultura de Panamá, 1980), 21-33. Nearly all the mules were imported from Nicaragua, as well as parts of Honduras and El Salvador (Castillero Calvo, Economía terciaria, 23-25; 1987; Linda A. Newson, The Cost of Conquest: Indian 
It was the practice for those crossing the isthmus to travel overnight to avoid the heat of the day. ${ }^{21}$ Most slaves would have slept in the open air, but small settlements with lodging houses for merchants and other travellers, would have been used by the slave traders. Expenses appear in the account books for accommodation at Boquerón, Pequeñí and Chagres, and also at Cruces for those travelling by the Chagres River. Slaves who were too sick to travel were often left for medical treatment at Portobello or one of these stopping points and caught up with the main group of slaves at a later date. On entry into Panamá the number of slaves was counted again to ensure that no slaves had been sold illegally on the isthmus. ${ }^{22}$ A local entrada tax of 12 reals was payable on each slave to pay for the construction of a bridge. ${ }^{23}$ Arriving at Panamá the slaves would be lodged at a nearby hato until they were boarded for the journey to Peru. Most commonly they were housed at an estate belonging to Antonio Franco, who supplied provisions in the form of beef and chickens. ${ }^{24}$ On this estate two huts were constructed to house the slaves together with a kitchen to serve them. The hut for male slaves measured 90 feet long by 22 feet wide and was regarded as very spacious, while a middle-sized one was built for female slaves. ${ }^{25}$ In these houses slaves were provided with boards to sleep on. A small number of other slaves were sometimes kept in a house rented by the slave traders, possibly because they were sick, but the sources are not clear. Large quantities of sackcloth were purchased for blankets, but probably for use on the journey to Peru rather than in Panama. The time spent near Panamá might vary between three and ten weeks, with the ships generally departing for Peru in January or early February. ${ }^{26}$

Societies in Honduras under Spanish Rule (Boulder, Col.: Westview Press, 1986), 141-42 and Indian Survival in Colonial Nicaragua (Norman and London: University of Oklahoma Press, 1987), 145.

${ }^{21}$ Gage, Travels, 327.

22 Bowser, African Slave, 63.

23 This tax was introduced in 1619 in order to fund the construction of a bridge in Panamá (AGI Panamá 35 N23 Jueces oficiales 3 Jul. 1636; AGNL SO CO Ca 20 doc 201 Money owed by Juan de la Cueva 1633).

${ }^{24}$ ANHS VM 77-I fols. 38-39 Pedro Duarte 1633 and 79 fols. 58-58v. Simón Váez Enríquez 19 Oct. 1633.

${ }^{25}$ ANHS VM 79 fol. 197 Pedro Duarte 31 Jan. 1633.

${ }^{26}$ AHNS VM 79 fols. 58-58v. Simón Váez Enríquez to Sebastián Duarte, Panamá, 19 Oct. 1633. In 1633 the slaves arrived at the hato on October 16, exactly one month after having left Cartagena. The second group arrived in November, but the slaves did not leave Panama until the last day of February the following year (ANHS VM 79 fols. 196-196v. Pedro Duarte 26 Feb. 1633). 
During the sojourn in Panamá the slave traders not only tended to their slaves, but as in Cartagena were probably also active in acquiring merchandise for sale in Lima that included contraband goods that arrived from Asia via the Philippines and Mexico. ${ }^{27}$

As in Cartagena, commercial activities in Panama were conducted through relatives and compatriots. Manuel Bautista Pérez initially used Felipe Rodríguez, who was one of Sebastián Duarte's uncles, with whom he often entered into a business partnership to sell slaves. After his death about 1627 to 1628, Sebastián Duarte's brother, Pedro Duarte, became his main agent, as well as business partner, in Panama. Pedro Duarte seems to have overseen in detail most aspects of the slave trade across the isthmus, arranging for the payment of taxes, as well as the accommodation, maintenance and onward shipment of the slaves and other merchandise to Peru. ${ }^{28}$ Pedro Duarte, like his brother, was prosecuted by the Inquisition in Cartagena and under torture confessed to being a Jew. ${ }^{29}$

\section{Slave Provisions in Panama}

Providing food for slaves during the few months they were in Panama involved an element of financial risk because the cost of provisions was quite variable, particularly in Portobello. This was partly because Panama depended heavily on food imports; agriculture was regarded as a less profitable economic pursuit than trade or its associated activities. ${ }^{30} \mathrm{~A}$ small number of vecinos made substantial profits through monopolising the provision of boats and mules for the isthmus trade, ${ }^{31}$

\footnotetext{
${ }^{27}$ Clayton, "Trade and Navigation," 5-6; Alfonso W. Quiroz, "The Expropriation of Portuguese New Christians in Spanish America 1635-1649," Ibero-Amerikanisches Archiv Jg. 11 H. 4 (1985): 413, 450; Minchin, "May You Always Care for Those of your Patria,," 157-60, 179-85.

${ }^{28}$ For some of his accounts see: ANHS VM 77-I fols. 37-37v., 40-40v., 38-39 Gastos con los negros que remitió mi hermano y trajo el año de 1633 and VM 77-I fols. 41-42 Gasto que hago con los negros de mi hermano, Pedro Duarte 1633; AGNL SO CO Ca 20 doc 201 Pedro Duarte con Capitán Pedro de Burgos 10 Feb. 1633.

${ }^{29}$ Medina, Inquisicón en Cartagena, 125; Anna María Splendiani, Cincuenta años de Inquisición en el Tribunal de Cartagena de Indias: 1610-1660 (Bogotá: Instituto Colombiano de Cultura Hispánica, 1997), vol. 3: 112.

${ }^{30}$ Manuel Serrano y Sanz, Relaciones históricas y geográficas de América Central (Madrid: Librería General de V. Suárez, 1908), 71 Relación histórica. Don Juan Requejo Salcedo [1640].

${ }^{31}$ Castillero Calvo, Economía terciaria, 26-29; Ward, Imperial Panama, 63-65.
} 
while others made good incomes through renting out houses. ${ }^{32}$ The development of agricultural enterprises was also hindered by shortages of labour and because many crops, such as wheat and barley that were in high demand could not be grown in its hot, humid climate. Even the maize that was grown was said to be of poor quality and fit only for horses and mules. ${ }^{33}$ Agricultural production was also hampered by the variable demand for provisions that was strongly linked to the arrival of the fleets and the fair at Portobello. ${ }^{34}$ Producers were reluctant to expand production when there was no guaranteed market and this problem became more acute in the seventeenth century when the arrival of the fleets became more irregular. In response agricultural producers placed greater emphasis on ranching than crop production, since it was more adaptable to the variable demand, while they sought to maintain profits through adopting monopolistic practices that restricted supply and maintained high prices. ${ }^{35}$ The agricultural economy thus came to be dominated largely by livestock raising and reliant on imports, which meant that the cost of provisions remained high. The Crown was aware of how critical the supply of provisions was for the operation of the fleet system and the flow of silver to Spain, so from the time that Portobello was founded in 1597 it enjoyed exemption from the payment of the taxes of almojarifazgo and alcabala on maize, wheat, chickens, wax, salted meat and other goods from Nicaragua, Cartagena and Veragua. ${ }^{36}$ These exemptions helped to reduce prices, ${ }^{37}$ but Panama struggled to meet the demand for provisions and it was said that at times its inhabitants were forced to subsist on plantains. ${ }^{38}$

From the earliest years of the colony Panama was unable to meet the demand for provisions and had to rely on food imports. In the

${ }^{32}$ Enriqueta Vila Vilar, "Las ferias de Portobelo: apariencia y realidad del comercio con Indias," Anuario de estudios americanos 39 (1982): 281-82.

${ }_{33}$ AGI Panamá 30 N23 doc 1 La ciudad de Panama 1583.

34 Ward, Imperial Panama, 61.

${ }^{35}$ Castillero Calvo, Economía terciaria, 14-16; María Carmen del Mena García, La ciudad en un cruce de caminos: Panamá y sus orígines urbanos (Seville: Escuela de Estudios Hispanoamericanos, 1992), 124; Ward, Imperial Panama, 61.

${ }_{36}$ AGI Panamá 32 N30 doc 1 Cabildo of Portobello, no date [1617].

37 When in 1634 this exemption had not been renewed, the price of maize rose from three to sixteen pesos a fanega (AGI Panamá 19 R1 N13 doc 1 Don Sebastián Hurtado de Corcuera 20 Jul. 1634).

${ }^{38}$ Mena García, Sociedad de Panamá, 111-12. 
sixteenth century tasajos, pigs, chickens and sugar were imported from Santo Domingo and other Caribbean islands, ${ }^{39}$ but in the seventeenth century most provisions, notably chickens, pigs and maize, came from Cartagena and Tolú in Colombia. Similar products came from Costa Rica via the port of Suerre, while honey, sugar, tobacco, chickens and some maize were shipped from Nicaragua via the Desaguadero. ${ }^{40}$ At the same time wheat flour, bizcocho, sugar, honey, conserves, beans and garbanzos came from Peru, and to a lesser extent Nicaragua.$^{41}$ Unfortunately this trade was highly variable due to difficulties with the weather, ${ }^{42}$ pirate attacks and government policies in regions of supply. ${ }^{43}$ Pirate attacks might not only destroy cargoes, but also divert agricultural labour into defence with adverse effects on production; goods from Nicaragua passing through the Desaguadero and along the Caribbean coast were under constant threat of attack. ${ }^{44}$ Even when there was no immediate crisis officials in Peru or Cartagena might introduce trade restrictions to prevent local shortages or contraband trade. ${ }^{45}$ The problem of assuring adequate food supplies in Panama was exacerbated by the hot humid climate which meant that provisions could not be stored for more than four or five months.

Despite the reliance on imports, the high prices for provisions did stimulate some local commercial agricultural production, notably the raising of cattle and the production of maize. Extensive pastures

39 López de Velasco, Geografia, 173.

40 CDI 9: 115 Descripción corográfica 1607; Mena García, Sociedad de Panamá, 109, 112; Descripción del virreinato del Perú, 117.

41 CDI 9: 91, 97 Descripción corográfica 1610; Serrano y Sanz, Relaciones históricas: 198-200 Descripción de Panamá 1607; Vázquez de Espinosa, Compendio, 212; Serrano y Sanz, Relaciones históricas, 39 Relación histórica Requejo Salcedo 1640.

42 For example earthquakes or flooding, most likely associated with El Niño, might adversely affect production on the coast of Peru (AGI Panamá 17 R 3 N39 Audiencia of Panama 27 Jun. 1619).

43 AGI Panamá 30 N23 doc 1 La ciudad de Panamá 1583, Panamá 17 R9 N159 doc 1 Don Rodrigo de Vivero y Velasco 28 Aug. 1624).

44 AGI Panamá 19 R4 N43 Don Henrique Henríquez 15 Jun. 1637.

45 For example, AGI Panamá 33 N119 Oficiales reales, Nombre de Dios 2 Mar. 1581, Panamá 32 N33 doc 1 Cabildo of Portobello [1620]. In 1654 when the Viceroy of Peru closed the ports of Peru in order to stem the illegal traffic in silver, Panama suffered from severe shortages of provisions, such that the price of wheat flour rose from 6 to 8 reals to 18 and 20 and was of poor quality, while maize increased from 20 and 24 reals a fanega to 100 and 120 , and a botija of rice rose from 20 and 24 reals to 64 (AGI Panamá 31 N58 Ciudad de Panamá 4 Dec. 1654). 
Table 6.2. Prices of Selected Foods Purchased for Slaves 1626 to 1634

\begin{tabular}{|c|c|c|c|c|c|}
\hline & Unit & Cartagena & Panama & Paita & Lima \\
\hline Beef & arroba & $4.5-5$ & $2-2.5^{1}$ & $\begin{array}{l}\text { Not } \\
\text { purchased }\end{array}$ & 4.5 \\
\hline Pork & piece & $64-160$ & $112-128$ & $\begin{array}{l}\text { No price } \\
\text { given }\end{array}$ & $\begin{array}{l}\text { Not } \\
\text { purchased }\end{array}$ \\
\hline Mutton & piece & $\begin{array}{l}\text { Not } \\
\text { purchased }\end{array}$ & $\begin{array}{l}\text { Not } \\
\text { purchased }\end{array}$ & $\begin{array}{l}\text { No price } \\
\text { given }\end{array}$ & 10 \\
\hline Chicken (gallina) & piece & $7-12(8.5)$ & $7-10(9)$ & $5-8(6)$ & 8 \\
\hline Fresh fish & arroba & $16-20(18)$ & $18-48$ & 11 & {$[16]^{2}$} \\
\hline Salt fish & arroba & $18-24(21)$ & $15-20(18)$ & $\begin{array}{l}\text { Not } \\
\text { purchased }\end{array}$ & $\begin{array}{l}\text { Not } \\
\text { purchased }\end{array}$ \\
\hline Turtle & piece & $8-76$ & $22-48$ & $\begin{array}{l}\text { Not } \\
\text { purchased }\end{array}$ & $\begin{array}{l}\text { Not } \\
\text { purchased }\end{array}$ \\
\hline Maize & fanega & $8-24(17)$ & 13-64 (33) & $18-32(29)$ & $16-22(19)$ \\
\hline Casabe & adorote & $24-40(17)$ & $\begin{array}{l}\text { Not } \\
\text { purchased }\end{array}$ & $\begin{array}{l}\text { Not } \\
\text { purchased }\end{array}$ & $\begin{array}{l}\text { Not } \\
\text { purchased }\end{array}$ \\
\hline Rice & botija & $24-30((27)$ & $18-32(24)$ & $\begin{array}{l}\text { Not } \\
\text { purchased }\end{array}$ & $\begin{array}{l}\text { Not } \\
\text { purchased }\end{array}$ \\
\hline Bizcocho & petaca & 176 & & & \\
\hline Bizcocho & quintal & & 68-96 (83) & $\begin{array}{l}\text { Not } \\
\text { purchased }\end{array}$ & $\begin{array}{l}\text { Not } \\
\text { purchased }\end{array}$ \\
\hline Beans & botija & $8-28(18)$ & & & \\
\hline Beans & costal & & $12-32(21)$ & & \\
\hline Beans & fanega & & {$[48]^{1}$} & 48 & $16-24$ \\
\hline
\end{tabular}

Average prices in reals are given in parentheses

Sources: 1628, 1630, 1633, 1634 AGNL SO CO Ca 20 doc 201

1626 and 1629 ANHS VM 77-II fols. 159-77, 252-265

For Lima see: ANHS VM 79 fols. 107, 108v. Expenses generated by slaves in Lima [1627]; AGNL SO-CO Ca 20 doc 201 Lo que se va gastando con los negros 1633 and Gasto que se va haciendo con los negros 1634 .

${ }^{1}$ CDI 9: 97-98 Descripción corográfica 1610; Serrano y Sanz, Relaciones históricas, 199 Relación histórica 1607.

${ }^{2}$ AGNL Cajas Reales, H-3, leg. 4, lib. 24a fols. 31-33 Abecedario de la tasa 1617.

existed in the hinterland of Panamá, especially the sabana de Pacora, and livestock raising had the advantage that it required little labour and was better adapted to fluctuations in demand. ${ }^{46}$ In 1609 there were 73 hatos with 88,000 head of cattle in the jurisdiction of Panamá and Nata, and there were a further 24 hatos with 23,600 cattle else-

\footnotetext{
${ }^{46}$ Mena García, Sociedad en Panamá, 104.
} 
where. ${ }^{47}$ The merchant traveller Francesco Carletti observed that in Panama there were some very rich ranchers who had so many catthe they could not count them. ${ }^{48}$ Despite conflicts between producers over access to markets, ${ }^{49}$ the beef produced in Panama was very cheap. According to local observers it generally sold for between two and two and half reals an arroba, which was considerably cheaper than in Cartagena (Table 6.2).$^{50}$ Furthermore the beef purchased for the upkeep of slaves appears to have been even cheaper, probably because it was supplied from the estate where the slaves were lodged. In 1633 a cow sold for 5 pesos. ${ }^{51}$ On the other hand, in Portobello it cost between 4 and 5 reals an arroba because it had to be imported. ${ }^{52}$

In Panama pigs and chickens were only raised in small quantities. Some pigs were raised in pens in the urban suburbs and some goats raised for milk within the city and on estates. ${ }^{53}$ However, most pigs were imported from Costa Rica and Cartagena and Tolú, ${ }^{54}$ such that pork was considerably dearer than beef. In 1610 pigs were selling at between 8 and 12 pesos each, ${ }^{55}$ and in the 1620s and 1630s for between 14 and 16 pesos. Not surprisingly the purchase of pigs does not figure significantly in the account books, with most being

47 AGI Panamá 46 N 27d Memoria de los hatos de ganado que hay [1609]. A copy of the list of those around Panamá and Nata is given in Mena García, Sociedad en Panamá, 127-29. See also CDI 9: 98 Descripción corográfica 1610; Serrano y Sanz, Relaciones históricas, 171 Descripción de Panamá 1607; Serrano y Sanz, Relaciones históricas, 72 Relación históricas Requejo Salcedo 1640.

${ }^{48}$ Carletti, Voyage, 32.

${ }^{49}$ AGI Panamá 30 N28 doc 1 Andrés Pérez de Salinas 12 Oct. 1591; Mena García, Sociedad de Panamá, 116-25.

${ }^{50}$ Descripción del virreinato del Perú, 117; Carletti, Voyage, 33. In 1607 a cow sold in Panama for between 18 and 22 reals, though the price varied during the year. Between Easter and San Juan beef sold for 2.5 reals an arroba and veal for 5 reals, and at other times of the year 2 reals and 4 reals respectively, and during Lent only veal was available at 8 reals (CDI 9: 97-98 Descripción corográfica 1610; Serrano y Sanz, Relaciones históricas, 199 Relación histórica 1607).

${ }^{51}$ Another account suggests that the price of an arroba of beef was one peso (ANHS VM 77-I ff.37-37v, 38-39, 40-40v Gastos con los negros que remitió mi hermano y trajo el año de 1633). This could have reflected a temporary shortage, because all other evidence suggests that beef was cheap.

${ }^{52}$ Thomas Gage was outraged that a pound of beef cost 2 reals in Portobello when elsewhere 13 pounds cost only 0.5 real (Travels, 330). This is most likely a considerable exaggeration but it draws attention to the high cost of provisions in Portobello.

${ }^{53}$ Serrano y Sanz, Relaciones históricas, 151 Descripción de Panamá 1607.

${ }^{54}$ CDI 9: 115 Descripción corográfica 1607.

${ }^{55}$ CDI 9: 98 Descripción corográfica 1610. 
bought for the journey, often in the form of suckling pigs, or for salting. There are few references to the raising of chickens in the colonial sources. ${ }^{56}$ In Portobello some chickens were raised on local chacras, but most were imported from Costa Rica and Nicaragua. ${ }^{57}$ Despite the absence of references to the raising of chickens, they sold for about the same price as in Cartagena; in 1606 they were selling at between 8 to 10 reals a piece, ${ }^{58}$ and the price did not change in the 1620s and 1630s (Table 6.2).

Fish were plentiful on both the Caribbean and Pacific Coasts; ${ }^{59}$ indeed Panamá took its name from the indigenous word for "a place of abundant fish" ${ }^{60}$ Nevertheless, fishing appears to have declined as an economic activity to the extent that by 1607 it was said that no fishing took place off Panamá. ${ }^{61}$ Fish was in such short supply that the church granted permission for local people to eat meat on Sundays, Tuesdays and Thursdays during Lent. ${ }^{62}$ Apparently they consumed iguana as a substitute for fish on Fridays. ${ }^{63}$ The shortage of fish was probably related to the widespread availability of cheap meat, but shortages of labour and the distain of Spaniards for fishing may have also been contributory factors. ${ }^{64}$ However, on the Caribbean Coast where cattle were scarce, "fish and tortoises [turtles]" were the cheapest forms of meat available. ${ }^{65}$ In Portobello turtles cost between about three and six pesos each according to size. ${ }^{66}$ Nevertheless it was said that slaves employed in the construction of Portobello would not eat fish, so that when meat was not available, they abandoned their work and sought food on distant haciendas. ${ }^{67}$ It is not clear whether this resistance to fish derived from a lack of familiar-

\footnotetext{
56 Though one account suggest they were abundant (Descripción del virreinato del Perú, 117).

57 CDI 9: 115 Descripción corográfica 1607.

58 AGI Panamá 62 N 49 doc 1 fol. 4 Información... sobre la necesidad que hay de acrecentar el salario 5 Aug. 1606.

59 CDI 9: 102, 117 Descripción corográfica 1610 and 1607.

60 Serrano y Sanz, Relaciones históricas, 68 Relación históricas Requejo Salcedo 1640.

61 Serrano y Sanz, Relaciones históricas, 143 Descripción de Panamá 1607.

62 Carletti, Travels, 33.

63 CDI 9: 100 Descripción corográfica 1610.

${ }^{64}$ Carletti, Voyage, 41. Here he was referring to the Peruvian coast, but the comment has general validity.

65 Gage, Travels, 368.

66 AGNL SO CO Ca 20 doc 201 Journals for 1626, 1628 and 1629.

67 AGI Panamá 14 Dr. de Villanueva Zapata 12 May 1595.
} 
ity with it in Africa or because in Panama they had become accustomed to eating meat.

Despite the difficulty of growing wheat in Panama's hot humid climate, bread made from wheat flour was preferred, though in times of shortage and for variety, all social groups consumed tortillas, bollos de maiz and plantains. ${ }^{68}$ In the early seventeenth century the price of bread was usually 0.5 real for 12 ounces, though it varied with the price of flour, ${ }^{69}$ and it was often double that price in Portobello. ${ }^{70}$ Maize was the main staple of slaves and those who lived outside the city. During the early colonial period maize was imported from Manta and Puerto Viejo in Ecuador or alternatively from Nicoya and Realejo in Nicaragua. ${ }^{71}$ However, maize production expanded around Panamá and in the hinterlands of the cities of Nata and Villa de los Santos, with the latter producing some 30,000 fanegas in $1575 .{ }^{72}$ Maize was grown on estancias under a system of shifting cultivation, for yields usually declined significantly in the second year after planting. ${ }^{73}$ However, production did not expand and may even have declined in the mid-seventeenth century due to fluctuations in demand related to the irregularity of the fleets and fairs at Portobello. As such Panama still depended on imports of maize. ${ }^{74}$ Maize generally sold for two to four pesos a fanega, which was about twice that in Cartagena, and it could rise to six or eight pesos. As with meat, hoarding to encourage higher prices was common practice, in this case by shopkeepers who monopolised the maize produced by farmers in Nata, Villa de los Santos and elsewhere. ${ }^{75}$ It seems that it was often cheaper for Portobello to import maize from Cartagena than for it to be transported from the other side of the isthmus.

\footnotetext{
${ }^{68}$ Serrano y Sanz, Relaciones históricas, 198 Descripción de Panamá 1607; Serrano y Sanz, Relaciones históricas, 77 Relación histórica Requejo Salcedo 1640; Mena García, Sociedad de Panamá, 105-107, 113-14.

${ }_{69}^{69}$ CDI 9: 97 Descripción corográfica 1610; Serrano y Sanz, Relaciones históricas, 198 Descripción de Panamá 1607.

${ }^{70}$ CDI 9: 115 Descripción corográfica 1607.

${ }^{71}$ AGI Panamá 16 R1 N5 Don Francisco Valverde de Mercado 23 May 1609.

72 Mena García, Sociedad en Panamá, 107.

73 AGI Panamá 16 R1 N5 Don Francisco Valverde de Mercado, 23 May 1609; CDI 9: 96 Descripción corográfica 1610; Serrano y Sanz, Relaciones históricas, 148 Descripción de Panamá 1607.

${ }^{74}$ AGI Panamá 17 R9 N159 doc 1 Don Rodrigo de Vivero y Velasco, 28 Aug. 1624.

75 AGI Panamá 31 N47 doc 1 Ciudad de Panamá 19 Jun. 1647.
} 


\section{Slave Rations in Panama}

It is more difficult to establish the rations given to slaves in Panama. Generally the expenses incurred in Portobello and Panamá are distinguished, but daily entries for Portobello only exist for one year. Another limitation is that in several accounts large payments were paid to individuals, but the goods and services they provided were not recorded. This is significant because in cases where some of the detail can be filled in from other accounts of expenditure, for example for the 1633 venture, it would appear that they were often payments for large quantities of provisions. An additional problem in calculating the total amount of food purchased is many of the entries give the prices of combinations of goods, such as "bread, candles and eggs", or refer only to "daily expenses". Finally, it is difficult to calculate the number of slaves that were being supported. A few slaves were sold locally and some fled during their stay in Panama, but the dates of these incidents are not recorded. Even though it is not possible to calculate the daily ration precisely, the accounts do give a clear indication of the composition of the slave diet, which was significantly different in Portobello than when they were lodged at an estate near Panamá (Table 6.3).

In Portobello the main protein consumed by the slaves was turtle (Table 6.4), though a few chickens and some beef were purchased

Table 6.3. Percentage of Expenditure on Different Categories of Food for Slaves 1626 to 1634

\begin{tabular}{lrrrr}
\hline & Cartagena & Portobello & Panama & Paita \\
\hline Meat & 22.9 & 9.6 & 9.9 & 3.7 \\
Chickens, other birds and eggs & 7.2 & 0.0 & 8.1 & 21.0 \\
Processed meats and cheese & 6.8 & 0.0 & 3.6 & 1.4 \\
Fish, salt fish and turtle & 5.4 & 42.2 & 0.7 & 25.5 \\
Bread (maize, casabe and other cereals) & 35.5 & 29.5 & 62.6 & 23.6 \\
Vegetables and fruit & 4.3 & 2.4 & 2.4 & 15.5 \\
Other foods & 17.9 & 16.3 & 12.7 & 9.3 \\
& 100 & 100 & 100 & 100 \\
\hline
\end{tabular}

Sources:

1628, 1630, 1633, 1634 AGNL SO CO Ca 20 doc 201

1626 and 1629 ANHS VM 77-II 159-77, 252-265

The figures for Cartagena are taken from all six accounts, those for Panama for 1626, 1628, 1629, and for Paita for 1626 and 1630. 
Table 6.4. Percentage of Expenditure on Different Foods for Slaves 1626 to 1634

\begin{tabular}{|c|c|c|c|c|}
\hline Cereals and bread & Cartagena & Portobello & Panama & Paita \\
\hline Maize & 67.8 & 100.0 & 46.9 & 83.4 \\
\hline Casabe & 16.5 & 0.0 & 0.0 & 0.0 \\
\hline Barley & 0.2 & 0.0 & 0.0 & 0.0 \\
\hline Rice & 0.6 & 0.0 & 3.9 & 0.0 \\
\hline Bizcocho & 2.8 & 0.0 & 43.2 & 0.0 \\
\hline Unspecified bread & 12.1 & 0.0 & 6.0 & 16.6 \\
\hline Total expenditure in reals & 33,698 & 984 & 43,327 & 1,340 \\
\hline Meat, fish and dairy products & Cartagena & Portobello & Panama & Paita \\
\hline Meat & 54.2 & 18.5 & 44.2 & 7.2 \\
\hline Chickens, other birds and eggs & 17.1 & 0.0 & 36.2 & 40.7 \\
\hline Processed meats and cheese & 16.0 & 0.0 & 16.3 & 2.7 \\
\hline Fish, salt fish and turtle & 12.7 & 81.5 & 3.3 & 49.4 \\
\hline Total expenditure in reals & 40,162 & 1,728 & 15,506 & 2,927 \\
\hline Fresh meat & Cartagena & Portobello & Panama & Paita \\
\hline Beef & 29.8 & 100.0 & 56.5 & 0.0 \\
\hline Beef and pork & 32.8 & 0.0 & 0.0 & 0.0 \\
\hline Pork & 17.4 & 0.0 & 10.4 & 7.6 \\
\hline Mutton & 0.0 & 0.0 & 88.6 & \\
\hline Mixed or unspecified meats & 20.0 & 0.0 & 33.1 & 3.8 \\
\hline Total expenditure in reals & 21,748 & 320 & 6852 & 211 \\
\hline Vegetables and fruit & Cartagena & Portobello & Panama & Paita \\
\hline Plantains & 41.6 & 100.0 & 21.3 & 0.0 \\
\hline Amaranth & 28.2 & 0.0 & 0.0 & 0.0 \\
\hline Beans & 5.5 & 0.0 & 52.8 & 10.9 \\
\hline Squashes & 14.9 & 0.0 & 24.5 & 60.8 \\
\hline Sweet potatoes & 0.0 & 0.0 & 0.0 & 7.2 \\
\hline Chickpeas & 0.0 & 0.0 & 0.0 & 4.8 \\
\hline Onions and cabbages & 2.4 & 0.0 & 0.0 & 3.6 \\
\hline Guavas & 2.9 & 0.0 & 0.0 & 0.0 \\
\hline Oranges and lemons & 4.7 & 0.0 & 1.3 & 5.9 \\
\hline Melons & 0.0 & 0.0 & 0.0 & 6.8 \\
\hline Total expenditure in reals & 4,067 & 80 & 1,662 & 883 \\
\hline
\end{tabular}

Sources:

1628, 1630, 1633, 1634 AGNL SO CO Ca 20 doc 201

1626 and 1629 ANHS VM 77-II 159-77, 252-265

The figures for Cartagena are taken from all six accounts, those for Panama for 1626, 1628,1629, and for Paita for 1626 and 1630. 
notably for the journey; the only other foods acquired were small amounts of plantains and maize. The slaves' diet changed markedly when they arrived near Panamá and were fed primarily on beef and bread. In 1633 Antonio Franco supplied 184 head of cattle and 22 arrobas of beef for the support of the slaves. ${ }^{76}$ Beef was generally preferred to pork because it was cheaper, but when it was not available pork was purchased, perhaps suggesting that the slave traders considered it important that the slaves received a ration of meat of some kind. ${ }^{77}$ The greatest expenditure on pork was in the form of suckling pigs that were commonly purchased prior to the journey to Peru. In 1633 chickens accounted for only a small proportion of the protein purchased, but the accounts for this year are incomplete and those relating to three consignments of slaves in the 1620 s indicate that chickens were acquired in large numbers, accounting for about one-third of the total expenditure on meat. ${ }^{78}$ The importance of chicken in the diet is also underlined by the inclusion of expenses for the construction and maintenance of hen houses while the slaves were in Panama.

Cereals and cereal products accounted for nearly two-thirds of the expenditure on food for the slaves, with about half spent on maize and half on imported bizcocho. Most of the bizcocho, in the form of both bizcocho blanco and bizcocho negro, was acquired in large quantities one or two days before the departure for Peru, but it was also purchased in the absence of casabe and when there were shortages of maize. ${ }^{79}$ Because of the poor quality of the maize, it was not fed to slaves when they were ill. ${ }^{80}$ Whether for this reason or because the slave traders preferred to feed the slaves foods with which they were familiar, much of the maize they were fed on the isthmus was in the form of couscous. ${ }^{81}$ Apart from maize, rice was grown locally

${ }^{76}$ ANHS VM 77-I fol. 38 Gastos con los negros que remitió mi hermano y trajo el año de 1633.

77 AGNL SO CO Ca. 20 doc 201 Memoria de los gastos que se hicieron con los negros 1631 .

78 The accounts for 1626, 1628 and 1629 indicate that chickens accounted for 33, 38 and 49 percent respectively of total expenditure on protein.

${ }_{79}$ The major suppliers of bizcocho were María Egipcíaca, Alferez Jorge de Silva and Joseph de Cuellar.

${ }^{80}$ AGI Panamá 14 Dr. de Villanueva Zapata 12 May 1595.

${ }^{81}$ It is clear from the number of bowls, mortars and baskets that were purchased that much of the maize was made into couscous, as was specified in a number of entries. 
on the banks of swamps and in sufficient quantities to enable it to be exported to Peru. ${ }^{82}$ Its availability and good storage qualities meant that it was purchased more often in Panama than in Cartagena, though it probably did not account for more than 10 percent of expenditure on cereals and bread on any one journey. ${ }^{83}$

Meat and bread accounted for about 75 to 85 percent of the total expenditure on food. Virtually no fish were purchased and the accounts for 1633 include a payment of 15 pesos for a dispensation to allow the slaves to eat meat on fish days. Vegetables and fruit accounted for less than 3 percent of expenditure. The Panamanian isthmus possessed an abundance of native and introduced fruits and vegetables; ${ }^{44}$ indeed Thomas Gage noted that "fish, fruits and herbage for salads" were more plentiful than meat. ${ }^{85}$ However, the commercial production of vegetables and fruits appears to have been limited, for in the early seventeenth century it was said there were no chacras raising vegetables and fruits around the city of Panamá, only a few huertas. ${ }^{86}$ The only vegetables and fruits purchased were plantains, guavas, oranges, lemons, beans and squashes (both zapallos and auyamas). Plantains were particularly abundant in Panama, where they were eaten raw, boiled roasted or stewed, and were regarded as a regular food of Africans. ${ }^{87}$ Even so, plantains appear to have made only a small contribution to the slave diet, being consumed

${ }^{2}$ CDI 9: 96-97 Descripción corográfica 1610; Serrano y Sanz, Relaciones históricas, 142 Descripción de Panamá 1607; Descripción del virreinato del Perú, 117.

${ }^{83}$ It is very difficult to calculate the precise percentage, because although the quantities of rice are generally recorded separately, the same is not true for bread where the entries often include other items. As such it is not easy to calculate the total expenditure on cereals and bread, and therefore the proportion spent on different types.

${ }^{84}$ CDI 9: 96-97, 114-15 Descripción corográfica 1610 and 1607; Serrano y Sanz, Relaciones históricas, 147 Descripción de Panamá 1607; Serrano y Sanz, Relaciones históricas, 73-75 Relación histórica Requejo Salcedo 1640; Descripción del virreinato del Perú, 117. Native fruits included mameyes (mamey sapote), caimitos (star apples), anonas (custard apples), guanábanas (soursops), guavas, pineapples, papayas, passion fruits, nisperos (sapodillas) and plantains, while introduced fruits included oranges, lemons, limes, plums, figs, grapes, pomegranates, quinces and melons.

85 Gage, Travels, 327.

86 Serrano y Sanz Relaciones históricas, 170 Descripción de Panamá 1607. See also Carletti, Voyage, 33.

87 Serrano y Sanz, Relaciones históricas, 147 Descripción de Panamá 1607, 74-75 Relación histórica Requejo Salcedo 1640. The local plantain was distinguished from a "plátano de Guinea" which was imported from Cartagena and said to be more tasty but not as good as a food (CDI 9: 115 Descripción corográfica 1607). 
in Portobello where other foods were in short supply or purchased for the journey. Similarly, beans and squashes were most often purchased just prior to departure. Guavas, which sold on the isthmus at 20 a real, were used to cure diarrhoea. ${ }^{88}$ In general fruit appears to have been purchased mainly for the sick and therefore bought in small amounts as the need required, rather than on a regular basis.

Sugar, honey and lard were important dietary supplements to the extent that expenditure on these items exceeded that on vegetables and fruit. In 1607 there were three trapiches in Panama, but no ingenios for the production of sugar, and the sugar that was produced was deemed inferior to that of Peru. Sugar sold for 4 pesos an arroba and miel de caña (sugar syrup) at three pesos a botija. ${ }^{89}$ These prices seem to have remained fairly constant through the 1620s and 1630s. Portobello seems to have obtained imported honey from bees and sugar cane from Nicaragua. ${ }^{90}$ As in Cartagena, the other major expenditure on non-staples was on lard, which would have been used extensively in cooking. In conclusion, the diet of slaves on their journey through Panama was similar to that to slaves employed in the country itself, where slaves employed in the construction of the port in the 1590 s were fed maize, beef, oil, beans or lard or honey. ${ }^{91}$

\section{Into the South Sea}

While the slaves were lodged at an estate, the ships that would transport them to Peru were being fitted out for the journey. The harbour at Panamá was shallow and exposed to the sea and the tides. In 1575 vessels of sixty tons could still dock at there at high tide, but the harbour gradually silted up so that in the early seventeenth century even small vessels found difficulty landing there and large ships had to moor some two leagues away at the island of Perico. ${ }^{92}$

${ }^{88}$ CDI 9: 97, 114 Descripción corográfica 1610 and 1607.

${ }^{89}$ Serrano y Sanz Relaciones históricas, 170, 199-200 Descripción de Panamá 1607.

${ }^{90}$ CDI 9: 115 Descripción corográfica 1607.

${ }^{91}$ AGI Panamá 44 N30g Memorial del gasto... las fortificaciones y fábricas reales deste Puerto de Puertobelo [1596]. See also AGI Panamá 14 Dr. de Villanueva Zapata 12 May 1595; Panamá 31 Informe y cuentas sobre la fábrica... 8 May 1626, 7 Mar. 1626.

${ }_{92}$ Carletti, Voyage, 34-35; Haring, Trade and Navigation, 187. 
Perico had deeper water, but it possessed no wharf, offered limited shelter and the movement of goods and passengers to and from the land was risky due to the undertow and marked changes in the tides. ${ }^{93}$ It was at Perico that the slave ships were fitted out for the journey to Peru. When the ship was ready, the slaves were transferred by rowing boat to the island, where they sometimes waited several days before being boarded onto the ship..$^{94}$ Before the ships departed their registers had to be drawn up and the value of the slaves assessed. The cost of valuation was four reals per slave, but further bribes were often required to facilitate the process. ${ }^{95}$

Manuel Bautista Pérez and Pedro Duarte, who normally made the contracts in Panama, used the same ships and shipmasters over a number of years, employing them not only to transport slaves and merchandise to Lima, but also to return to Panama with other goods. A ship generally undertook only one return trip a year. ${ }^{96}$ In most years Pérez's annual consignment of slaves was transported on board two ships. ${ }^{97}$ In the early 1630s he was employing Pedro de Burgos and Andrés Meléndez who were shipmasters of the Santiago and San Joseph respectively. ${ }^{98}$

Little is known about the merchant vessels that operated on the Pacific Coast, of which there were probably between forty and sixty

${ }^{93}$ CDI 9: 102-103 Descripción corográfica 1607; Serrano y Sanz, Relaciones históricas, 40; AGI Panamá 89 Don Inigo de Lara 8 Sep. 1672; López de Velasco, Geografia, 173; Gage, Travels, 326-27; Mena García, Cruce de caminos, 61-71.

94 AGNL SO CO Ca 20 doc 201 Journal for 1630.

${ }^{95}$ AGNL SO CO Ca 18 doc 197 p. 725 Upper Guinea accounts 1613-1618; AGNL SO CO Ca 20 doc 201 Money owed by Juan de la Cueva 1633.

${ }_{96}$ Pedro de Burgos in the ship Santiago left Panama for Lima on 28 February 1633 and arrived back in Panama on 22 September 1633. It began loading in Panama in 19 October 1633 but did not arrive in Lima until 4 February 1634 (ANHS VM 79 fols. 196-196v. Pedro Duarte 26 Feb. 1633; VM 79 fols. 60-60v. Simón Váez Enríquez 24 Sep. 1633; VM 79 ff. 58-58v. Simón Váez Enríquez 19 Oct. 1633; AGNL SO CO Ca 40 doc 383 fols. 304-305v. Tribunal del Consulado 1636. One journey in 1609 took over nine months from Paita to Lima with the ship having been forced back to Paita twice (AGNL Consulado Caja 144 fols. 268-316 Diego Abarez 16 Apr. 1613). Clayton also judges that only one round trip was possible a year (Lawrence A. Clayton, "Notes on a Shipwreck", South Eastern Latin Americanist, 17(4)(1974): 3).

${ }_{97}$ When there were fewer slaves to transport, as was the case in 1631 when he only purchased 150 slaves, only one was used.

98 AGI Lima 45 and 46 Navíos que han entrado al puerto del Callao ... desde 14 Jan. 1629 para adelante 15 May 1635 and AGNL SO CO Ca 40 doc 383 fols. 304-305v Cuenta con Manuel Bautista Pérez de la avería de entrada de negros $1631-1635$. 
of between 150 and 350 tons in the early seventeenth century. ${ }^{99}$ Pablo Pérez Mallaína describes the construction of galleons that served in the Armada del Mar del Sur. ${ }^{100}$ These galleons were sometimes used to transport cargo, but their decks were generally higher than those of merchant vessels due to the need to position artillery above the water level. According to the Italian merchant traveller Francesco Carletti merchant ships had only one deck in order to stow as much cargo as possible. He observed that because the ships were constantly sailing against the winds they were wide from the middle towards the prow and narrow towards the poop and they had no superstructure built above the first deck from the mainmast down. As a result only the captain and a few passengers could be accommodated in the poop, while the rest had to remain on deck uncovered day and night and exposed to any inclement weather. ${ }^{101}$ Although some slaves were being transported on the vessel described by Carletti, he gives no account of how the slaves were accommodated. The open nature of merchant ships is also suggested in a letter from Manuel Bautista Pérez, who describing his journey to Peru in 1619, said he feared for the safety of the ship because so many people were collected on the deck. ${ }^{102}$ Nevertheless, ships carrying large numbers of slaves probably accommodated them below deck and in some cases, such as with the Santiago, may have had two decks. ${ }^{103}$ The high loss of life associated with shipwrecks, as in the case of the Nuestra Señora del Rosario near Callao in 1632, when 120 of the 125 slaves aboard were drowned, also suggests that slaves were being carried below deck. ${ }^{104}$ Similarly 103 lives were lost in a shipwreck off the coast of Panama the following year, because it was said that there was so much cargo aboard that the passengers that included 190 slaves had to be transported below deck. ${ }^{105}$

\footnotetext{
${ }^{99}$ Clayton, "Notes on the Shipwreck," land "Trade and Navigation," 1, 6; Peter Bradley (personal communication, 10 Jan. 2003). See also Woodrow W. Borah, Early Colonial Trade and Navigation between Mexico and Peru (Berkeley and Los Angeles: University of California, 1954), 66-68.

${ }_{100}$ Pablo E. Pérez Mallaína and Torres Ramírez, Bibiano, La Armada del Mar del Sur. (Seville: Escuela de Estudios Hispanoamericanos, 1987), 110-111.

${ }^{101}$ Carletti, Voyage, 35.

${ }^{102}$ AGNL SO CO Ca 18 doc 197 Manuel Bautista Pérez 24 Apr. 1619.

103 AGNL SO CO Ca 20 doc 201 Contract between Capitán Pedro de Burgos and Capitán Pedro Duarte 10 Feb. 1633.

${ }_{104}$ AGI Lima 43 Book for 1632 fols. 21-23 Conde de Chinchón 12 Mar. 1632

105 ANHS VM 79 fols. 197-199 Pedro Duarte 31 Jan. 1633.
} 
Merchant vessels were particularly prone to shipwreck because they only made one round trip a year between Panama and Peru and there was therefore a tendency to use large ships and to overload them making them less manoeuvrable. ${ }^{106}$ Although poor navigation contributed to the shipwreck of the Nuestra Señora del Rosario in 1632 it was mainly attributed to overloading, prompting the viceroy, the Conde de Chinchón, to request that ships be inspected in Panama before departing for Peru. ${ }^{107}$ With such crowded conditions on board, the space for slaves would have been minimal.

Ships operating in the South Sea that carried cargo from Lima to Panama, had to be specially fitted out for the transport of slaves on the return journey. A contract between Pedro Duarte with the captain of the Santiago, Pedro de Burgos, for the transport of 270 slaves to Callao in 1633, specified that he was to supply two dozen wooden boards, which were for the slaves to sleep on, and to provide a storeroom with a separate key for the slaves' provisions, a separate galley for cooking the slaves' food, and space for bottles of water for sick slaves on the deck and forecastle. ${ }^{108}$ The slaves were also to be provided with blankets at twelve reals apiece, which Manuel Bautista Pérez insisted should be made of good quality material and not coarse cloth, which was bad for them though he didn't say why. ${ }^{109}$ Burgos was to be paid 13 pesos ensayados for each slave transported. ${ }^{110}$

106 Clayton, "Notes on the Shipwreck", 3. For insight into living conditions on ships, though on the Atlantic crossing see: Pérez Mallaina, Spain's Men of the Sea, 129-140, where he calculates that each person might have 1.5 square metres of space (p. 131).

107 AGI Lima 43 Book for 1632 fols. 21-23 Conde de Chinchón 12 Mar. 1632; Clayton, "Notes on the Shipwreck", 1-5. The ship was probably between 300 and 500 tons and was carrying 1,500 boxes of cloth, 150 cakes of wax, 69 Spaniards and 125 slaves.

108 AGNL SO CO Ca 20 doc 201 Contract between Pedro de Burgos and Pedro Duarte 10 Feb. 1633.

109 ANHS VM 79-II fol. 12v. Manuel Bautista Pérez 1.7.1633. For the provision of mantas see: ANHS VM 79 fols. 189-190v. Pedro Duarte 14 Mar. 1633; AGNL SO CO Ca 20 doc 201 Money owed by Juan de la Cueva for the purchase and upkeep of slaves (1633); AGNL SO CO Ca 18 doc 197 p. 725 Uppewr Guinea accounts 1613-1619.

110 AGNL SO CO Ca 20 doc 201 Money owed by Juan de la Gueva, for the purchase and upkeep of slaves 1633. See also the contract the following year with the shipmaster, Captain Andrés Meléndez, who was paid 13 pesos (of 8 reals) for the transport of each slave from Panama to Lima (ANHS VM 77-I fol. 29 Concierto de Sebastián Duarte y Capitán Andrés Meléndez 4 Apr. 1634). 
The account books include numerous references to provisions purchased in Panama for the journey to Peru. In March 1633 Pedro Duarte reported that for the support of 211 piezas for the journey to Lima he had embarked in the Santiago 65 good sacks of couscous, 61 quintales of bizcocho, 7 arrobas of beef and a lot of honey and lard. ${ }^{111}$ Unfortunately it is not clear whether the provisions loaded on board were expected to cover the journey to Paita only or the whole voyage to Lima. Other accounts also indicate that bizcocho was one of the main sources of food on board ship, much of it being purchased from one supplier in Panama, María Egipcíaca. The bizcocho would not have been produced locally but imported from Peru or Nicaragua. In Panama slaves awaiting transhipment were generally fed maize in the form of couscous and this continued during the journey. The couscous was prepared in Panama prior to sailing, probably because its preparation was labour intensive; the maize that was loaded onto the ships was fed to chickens. Live chickens and suckling pigs were also loaded, and sometimes some fresh fish or meat for the first few days. Apart from large quantities of bizcocho and couscous, the San Pablo, which carried slaves and merchandise to Peru in 1627, had two chicken coops containing 106 chickens and a pen for 17 suckling pigs. ${ }^{112}$ Other provisions included eggs, salt fish and some preserves, including quince preserve that was used for sick slaves. Beans, rice and sugar also figured occasionally. Many of these items, notably the flour, sugar, conserves, chickpeas and beans were imported from Peru, ${ }^{113}$ while the suckling pigs and chickens probably came from Costa Rica and Peru. These provisions are consistent with those ordered for ships of the Armada del Mar del Sur, which were required to carry up to 30 and 80 chickens, depending on the size of the ship, and 4 arrobas of conserves for the treatment of the sick. ${ }^{114}$

111 AHNS VM 79 fols. 189-190v. Pedro Duarte 14 Mar. 1633.

112 AHNS VM 79 V. 155-156 Memoria de lo que voi enbarcando con ... San Pablo 1627 Manuel Bautista Pérez 1627. Similar items were loaded for the transhipment in 1618 (AGNL SO CO Ca 18 doc 197 Accounts for 1618-1619).

${ }_{113}$ Serrano y Sanz, Relaciones históricas, 171 Descripción de Panamá 1607; CDI 9: 91, 97 Descripción corográfica 1610c.

114 AGI Lima 38 Asiento del Armada del Mar del Sur con Capitán Lea Plaça y Lorenço de Mendoça 18 Apr. 1619. 


\section{The Fourney to Peru}

The journey from Perico to Paita, which was usually the first stopping point on the journey to Callao, regularly took about two weeks. ${ }^{15}$ However the journey from there onwards was less predictable due to the northward flowing Humboldt Current that often caused ships to be blown back up the coast. Here navigation was difficult and ships had to stick close to the shore, while finding a safe landing at Callao might take ten, twelve or even twenty days. ${ }^{116}$ A good voyage from Paita to Callao lasted forty to fifty days, but the journey often took more than two months, and even a year. ${ }^{117}$ Manuel Bautista Pérez's two journeys in 1619 and 1621 each took just over seventy days. ${ }^{118}$ Because of the unpredictability of the journey south from Paita, passengers often disembarked there and continued their journey overland. When the Marqués de Guadalcázar arrived in Peru from Mexico in 1622, he chose to take the overland route to Lima. This took nearly three months, but he regarded it as a wise decision because the ship that had left him in Paita took four months. ${ }^{119}$ Ships continuing the journey south might stop at Huaura, Santa or Trujillo. In Trujillo the harbour was unsheltered and conditions dangerous, ${ }^{120}$ but here slaves might also be disembarked to continue their

115 The length of journeys seems to have varied between 10 and 17 days. See also RGI 2: 33 Relación de la ciudad de Piura, no date.

${ }^{116}$ Lawrence A. Clayton, Los astilleros de Guayaquil colonial. Colección monográfica, Archivo Histórico del Guayas no. 11 (Guayaquil: Archivo Histórico del Guayas, 1978), 60; Pérez-Mallaína and Torres Ramírez, Armada del Mar del Sur, 194.

117 RGI 2: 33 Relación de la ciudad de Sant Miguel de Piura, no date; Peter T. Bradley, The Ships of the Armada of the Viceroyalty of Peru in the Seventeenth Century," The Mariner's Mirror 79(4)(1993): 394-5; Guillermo Lohmann Villena, Historia marítima del Perú: Vol. IV Siglos XVII y XVIII (Lima: Instituto de Estudios Histórico-Marítimos del Perú, 1981), 227; Pérez-Mallaína and Torres Ramírez, Armada del Mar del Sur, 201.

118 AGNL SO CO Ca 18 doc 197 Manuel Bautista Pérez 24 Apr. 1619 and 28 Apr. 1621. On the first voyage it took 76 days to Callao and on the second voyage it took 14 days to Paita and 57 days to Callao. Peter Bradley ("Ships of the Armada", 394-96) suggests that the average journey from Panama to Lima regularly lasted four months and sometimes six months and Marie Hellmer "Le Callao (1615-1618)." Jahrbuch fï Geschichte von Staat, Wirtschaft und Gesellschaft Lateinamerikas 2 (1965): 176) five to twelve months. Most likely the longer lengths of journeys suggested by Hellmer can be explained by the fact she is discussing smaller merchant vessels that often stopped at a number of points along the coast.

119 AGI Lima 39 N15 El Marqués de Guadalcázar 15 Dec. 1622.

${ }_{120}$ AGI Lima 111 Cabildo of Trujillo 24 Mar. 1614; López de Velasco, Geografia, 238. 
journey overland. ${ }^{121}$ It was said that the best time to travel southwards was between September and December ${ }^{122}$ but in the early 1630s at least most ships were arriving between January and April. ${ }^{123}$

\section{On the Coast of Peru}

The best port on the coast between Perico and Callao was Paita and this was the first stopping point for the majority of ships leaving Panama. It had a deep and safe harbour and it was exaggeratedly claimed that one thousand ships could anchor in its bay. ${ }^{124}$ However the port lacked water which had to be brought on rafts by sea from Colán about a league away and consequently it was very expensive. ${ }^{125}$ Nevertheless, it was at Paita that ships stopped for provisions and slaves were commonly unloaded to continue their journey overland. Here the almojarifazgo, a five percent value-added tax on the difference in price between Panama and Peru, was paid on specified goods that included slaves. Since prices varied considerably according to the market and quality of the slaves, this tax was often quite arbitrary. The minimum payable was two and a half pesos per slave though it might be as much as twenty pesos. ${ }^{126}$ During the early seventeenth century the almojarifazgo paid on each slave landed at Paita was 3.5 pesos (of 13.5 reales ensayados). ${ }^{127}$

${ }^{121}$ This was the case with a consignment of slaves in the frigate, Nuestra Señora de la Fuente, owned by Diego de León, when 132 were disembarked, while 8 continued the journey by ship (AGNL SO CO Ca 20 doc 201 Journal for 1634).

122 RGI 2: 33 Relación de la ciudad de Sant Miguel de Piura, no date. In the sixteenth century it was suggested that the average time taken from Panama to Callao was 60 days (RGI 2: 33 Relación de la ciudad de Piura, no date).

${ }^{123}$ AGI Lima 45 and 46 Navíos que han entrado al puerto del Callao... desde 14 Jan. 1629 para adelante 15 May 1635. Of the 91 ships entering Callao from Panama between January 1629 and February 1635, two-thirds arrived between January and April.

${ }_{124}$ RGI 2: 34 Relación de la ciudad de Sant Miguel de Piura, no date; López de Velasco, Geografia, 224; Vázquez de Espinosa, Compendio, 277.

${ }^{125}$ RGI 1: 125 Salazar de Villasante, no date [1571?]; Vázquez de Espinosa, Compendio, 277. On the 1630 journey 12 pesos were spent on water. In the early seventeenth century 3 botijas of water cost 1 real (Luis M. Glave, "La puerta del Perú: Paita y el extremo norte costeño, 1600-1615," Bulletin de l'Institut Français d'Études Andines 22(2) (1993): 506), but by 16301 real could only buy one botija (RGI 1: 253).

${ }_{126}$ Bowser, African Slave, 68, 370-71.

${ }_{127}$ Glave, "Puerta del Perú," 515-16. 
Due to the influence of the cold Humboldt Current the prevailing westerly winds carry little moisture so that the coast of Peru is arid and even when the air is forced to rise as it reaches the Andes and the moisture condenses, it does not bring rain, but forms only a fog or garúa. The coast is therefore dependent on water from the Andes that is supplied by seasonal rivers and irrigation systems. The journey south from Paita passed along the arid narrow coastal strip, known as the Llanos or, because they were broken up by irrigated valleys, as "los valles". These valleys produced large quantities of provisions, particularly wheat, maize and sugar cane and conserves, which not only supplied passing travellers but also supported Lima and an export trade to Central America. ${ }^{128}$ Agricultural production in these northern valleys had been stimulated by the exemption from almojarifazgo on provisions destined for regions to the south ${ }^{129}$ and by establishment of a number of new towns, such as Santa in 1557 and Saña in $1563 .{ }^{130}$ Due to the decline in the native population on the coast, ${ }^{131}$ agricultural production there depended on African slave labour despite the high capital investment involved. ${ }^{132}$ It was therefore common for small numbers of slaves to be sold on the route from Piura to Lima. In 1626 there were said to be 12,000 slaves in the jurisdiction of Trujillo. ${ }^{133}$

128 Vázquez de Espinosa, Compendio, 275-78; Descripción del Virreinato, 22-30; Reginaldo de Lizárraga, Descripción breve de toda la tierra del Perú, Tucumán, Río de la Plata y Chile. Biblioteca de autores españoles 216 (Madrid: Ediciones Atlas, 1968), caps. 9-20: 10-18 passim; Lohmann Villena, Historia maritima 4: 215-16; Marie Hellmer, "Le Callao (1615-1618)," Jahrbuch fur Geschichte von Staat, Wirtschaft und Gesellschaft Lateinamerikas 2 (1965): 183-84; AGI Lima 111 Cabildo of Trujillo 24 Mar. 1614; Katharine Coleman, "Provincial Urban Problems: Trujillo, Peru, 1600-1784," in Social Fabric and Spatial Structure in Colonial Latin America, edited by David J. Robinson (Ann Arbor: University Microfilms International), 381.

129 Lohmann Villena, Historia maritima 4: 226.

130 Robert G. Keith, Conquest and Agrarian Change: The Emergence of the Hacienda System on the Peruvian Coast (Cambridge, Mass.: Harvard University Press, 1976): 84; Susan E. Ramírez, Provincial Patriarchs: Land Tenure and the Economics of Power in Colonial Peru (Albuquerque: University of New Mexico Press, 1985): 63-64.

131 For an account of the decline of the population on the north coast of Peru see: Noble David Cook Demographic Collapse: Indian Peru 1520-1620 (Cambridge: Cambridge University Press, 1981): 116-44, who has estimated that between 1570 and 1620 the tributary population of the northern coast of Peru declined from 20,398 to 5,844 (p. 118). Around Piura alone the number fell from about 14,250 in 1545 to about 1,500 in 1600 (p. 125).

132 Bowser, African Slave, 88-96; Ramírez, Provincial Patriarchs, 110.

133 AGI Lima 156 Licenciado Juan Muñoz de Hoyo al rey, sobre suspensión de 
The most difficult stretch of the coast was the "despoblado de Sechura" just south of Piura where temperatures could rise to over 40 degrees centigrade and there was no water. This very arid region could be crossed in two days or else a longer route could be taken around it. ${ }^{134}$ Olmos de los Arrieros located immediately to the south of the "despoblado" was a town of muleteers who met ships arriving in Paita and accompanied travellers south to Lima at a charge of forty to fifty pesos. ${ }^{135}$ From Olmos the route led through Lambayeque, Saña, Trujillo, Santa and Guambacho, negotiating a number of difficult crossings at the Jequetepeque, Chicama, Santa and Pativilca Rivers, particularly in the rainy season. ${ }^{136}$ An anonymous account written about 1615 provides details of the overland route to Lima and agricultural production in the valleys. ${ }^{137}$ The whole distance from Paita to Lima was 180 leagues and a normal journey might take thirty days. ${ }^{138}$ Travel took place from late afternoon and overnight, rather than during the day. ${ }^{139}$ Slaves would have made the journey on foot, though sick slaves probably travelled by mule. Although provisions were abundant in the irrigated valleys, this was a tiring journey at the end of a long passage that must have sapped the strength of already weakened slaves.

During the journey south provisions to support the slaves were relatively abundant in the irrigated valleys. In the 1620 s wheat and maize cost two to three pesos and one and a half to two pesos a fanega respectively, ${ }^{140}$ while a wide range of native and European

la mita. 2 Feb. 1626; RGI 2: 44 Relación de la ciudad de Sant Miguel de Piura, no date. See also AGI IG 2796 Capitán Fernando de Silva Solís, no date.

${ }^{134}$ Susana Aldana, Empresas coloniales: las tinas de jabón en Piura (Lima: Centro de Investigación y Promoción del Campesinado and Instituto Francés de Estudios Andinos, 1988), 54.

${ }^{135}$ Vázquez de Espinosa, Compendio, 277.

136 Aldana, Empresas coloniales, 55.

137 Descripción del Virreinato, 22-30. See also Rubén Vargas Ugarte, Relaciones de viajes (siglos XVI, XVII y XVIII): Vol. 5. (Lima: Compañía de Impresiones y Publicidad, 1947), 111-14 Viaje que Juan de Herrera y Montemayor hizo el año 1617. See also Martín de Murúa, Historia general del Perú. Vol. 2 (Madrid: Instituto Gonzalo Fernández de Oviedo, 1964), 215-26.

${ }_{138}$ Vargas Ugarte, Relaciones de viajes, 111-14 Viaje que Juan de Herrera y Montemayor hizo el año 1617. From Piura to Olmos was 3 days, from Olmos to Saña 7 days, subsequently 5 days from there to Trujillo and finally 7 days to Lima. These times exclude lodging time in the towns.

${ }_{139}$ Vázquez de Espinosa, Compendio, 275-77.

140 RGI 2: 37 Relación de la ciudad de Sant Miguel de Piura, no date; Descripción 
crops was cultivated including chickpeas, lentils, melons, citrus fruits, cucumbers and aubergines. For the most part the journey south to Lima followed an inland route, but fish were plentiful on the coast, especially in Paita, but also in Lambayeque, which was close to the sea. ${ }^{141}$ The inhabitants of Paita were regarded as great fishermen and fresh fish, particularly dogfish and mullet, were always available, and sardines, swordfish and tuna were also caught. ${ }^{142}$ In fact ships often took on board fish, especially dogfish, and fish products for sale further south. ${ }^{143}$ Sheep were raised in the Piura Valley, ${ }^{144}$ but elsewhere on the coast the shortage of pasture meant that they were raised in the neighbouring hills. ${ }^{145}$ In Piura a sheep cost one peso or less and goats half a peso, but pigs, cattle and llamas (ovejas de la tierra) were between five and six pesos. ${ }^{146}$ Some livestock were raised in irrigated valleys, but due to the seasonal availability of water, the pasture often had to be supplemented by green wheat, barley or maize. The coastal towns were largely supplied with meat by the more inland provinces of Chachapoyas and Huánuco or even Quito. ${ }^{147}$

The food purchased for slaves reflected the availability of foods on the coast. On the 1630 journey fish, in the form of dogfish and tuna, constituted the single most important item of expenditure in Paita, followed by maize, chickens and mutton. In fact meat accounted for less than 4 percent of the total expenditure on food. Large quantities of vegetables were also purchased, especially squashes, which accounted for over two-thirds of the expenditure on vegetables, but also sweet potatoes and lima beans. ${ }^{148}$ This diet reflects the dominance of indigenous subsistence traditions. When Manuel Bautista

del Virreinato, 22-30; Glave, "Puerta del Perú", 506. The 1630 journal gives the price of maize as 4 pesos a fanega (AGNL SO CO Ca 20 doc 201 Journal for 1630 ).

141 Vázquez de Espinosa, Compendio, 276.

142 RGI 1: 125-26 Salazar de Villasante, no date [1571?]; RGI 2: 38 Relación de la ciudad de Sant Miguel de Piura, no date; Vázquez de Espinosa, Compendio, 277; Glave, "Puerta del Perú", 510, 517-18.

${ }^{143}$ Glave, "Puerta del Perú", 517. Glave calculates that between 1600 and 1606 no less than 178,000 tollos (dogfish) were exported.

144 Vázquez de Espinosa, Compendio, 278.

145 RGI 1: 124 Salazar de Villasante, no date [1571?].

146 RGI 2: 38 Relación de la ciudad de Sant Miguel de Piura, no date.

147 RGI 1: 124 Salazar de Villasante, no date [1571?].

148 AGNL SO CO Ca 20 doc 201 Journal for 1630. Some chickpeas were also purchased. 
Pérez undertook this journey himself in 1619 in Paita he purchased dogfish, mutton, maize, pumpkins, plantains, bread and potatoes. This particular consignment of slaves continued the journey by sea, and at Huaura, twenty leagues from Lima, the ship took on board nine quintals of bizcocho, thirty-four fanegas of maize, honey, bread, beans and fish. ${ }^{149}$ On the coast slaves benefited from fresh food, whereas rations consumed at sea comprised more processed foods such as bizcocho and salted meat, as was the case with rations provided for seamen on the Armada del Mar del Sur. ${ }^{150}$

\section{Arrival in Lima}

On arrival in Callao, the port of Lima, the slaves were inspected to ensure that they were not carrying any disease and assessments were made of the taxes payable. ${ }^{151}$ These included the payment of almojarifazgo, unless it had been previously paid in Piura or Trujillo, as well as a head tax of twenty five reals, known as cimarrones, which was levied to finance the capture of fugitive slaves. ${ }^{152} \mathrm{In}$ addition a nine reals customs tax was payable and on top of this one peso had to be paid for the valuation of each slave. This came to a total of about eleven pesos per slave. ${ }^{153}$ Once these formalities had been completed the slaves could be taken to lodgings in Lima.

In the early days of the slave trade slaves arriving in Lima were lodged in houses within the city that belonged to or were rented by the slave traders. Due to the health risk this posed, in 1624 the cabildo suggested that a large compound should be established on the northern side of the Rímac River in the district of San Lázaro. ${ }^{154}$ For this purpose the Viceroy, Marqués de Guadalcázar, imposed a tax of one peso on each arriving slave to support the construction

\footnotetext{
149 AGNL SO CO Ca 18 doc 197 Accounts for 1618-1619.

${ }^{150}$ Glave, "Puerta del Perú," 503-508.

151 Bowser, African Slave, 66.

152 AGNL SO CO Ca 20 doc 201 Money owed by Juan de la Cueva, for the purchase and upkeep of slaves (1633). In the sixteenth century the tax appears to have been two pesos (Bowser, African Slave, 67-68).

${ }_{153}$ AGNL SO CO Ca 20 doc 201 Slave purchases 1629; Money owed by Juan de la Cueva, for the purchase and upkeep of slaves (1633).

${ }^{154}$ LCL 19: 826-28 Cabildo of Lima 18 Mar. 1624.
} 


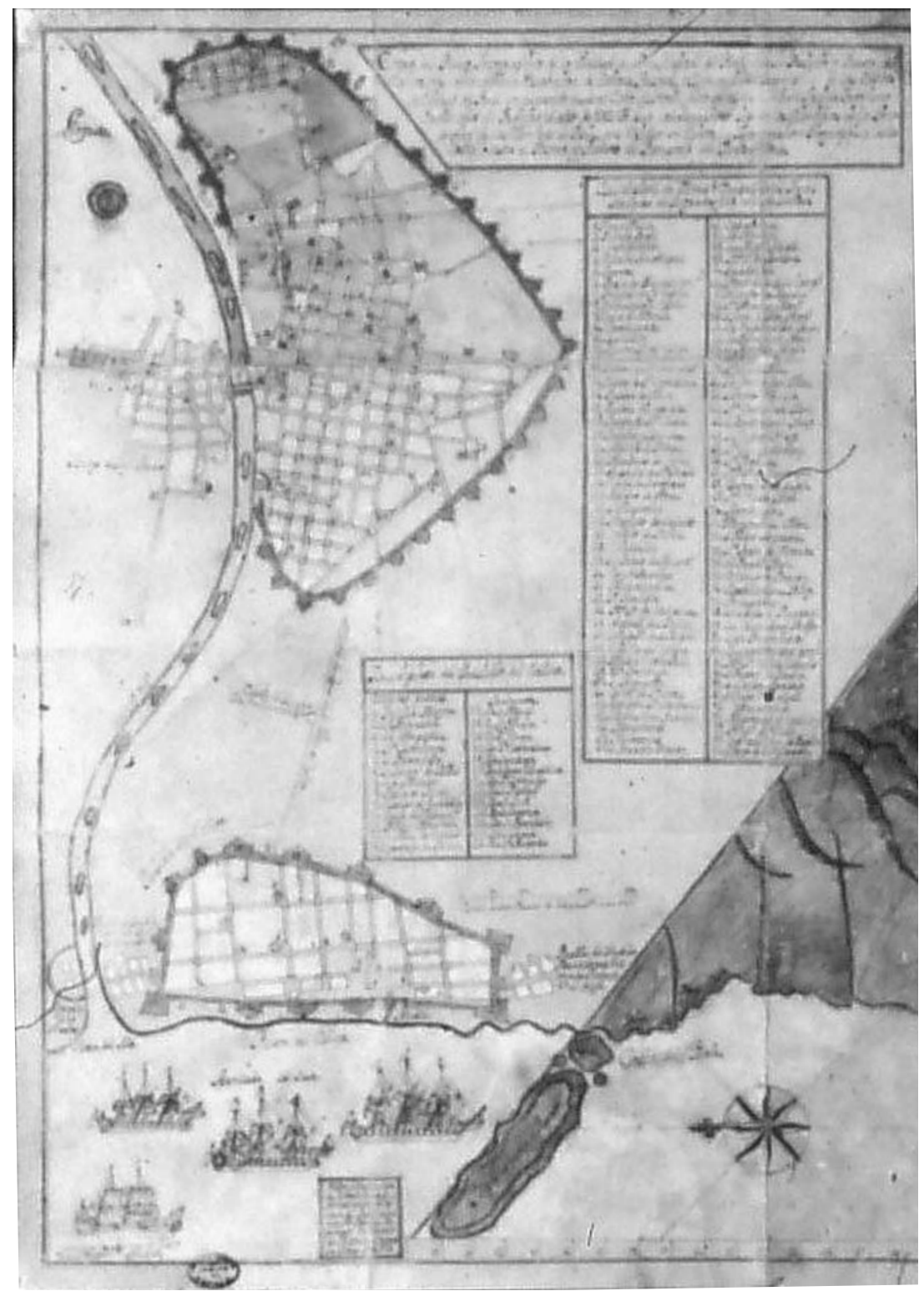

Figure 6. Lima and Callao in 1740. (Courtesy Spain. Ministerio de Cultura. Archivo General de Indias. Mapas y Planos Perú y Chile 22 Copia del Plano Topográfico de la Ciudad de Perú, y de sus Presidio y Puerto del Callao, 1740). 
of four separate quarters for slaves. ${ }^{155}$ They were not built, however, until the early 1630s under the subsequent viceroy the Conde de Chinchón, when four houses with yards were constructed in the district of San Lázaro so that men and women over the age of ten could be housed separately. ${ }^{156}$

In the 1620s Manuel Bautista Pérez's slaves appear to have been lodged in rented houses ${ }^{157}$ but this changed once he acquired a chácara at Bocanegra and accommodation was provided at San Lázaro. In the 1630s it seems that his slaves did not go direct to San Lázaro. When one of his consignments of slaves arrived on December 1st 1634 the men and women were separated with the men being taken to his chácara at Bocanegra and the women kept in the house of one Juan Ruiz. ${ }^{158}$ The slaves were then visited at Bocanegra by Doctor Juan de Vega on December 16th and declared free of "achaques [ailments] ni enfermedad alguna de contagio." 159 They were then allowed to enter the city where they were put in a compound in San Lázaro for which the slave traders normally paid a rent of about 300 pesos. ${ }^{160}$ The slaves appear to have been kept at the estate and transferred to San Lázaro in small batches. At the end of April the same year 36 slaves out of a consignment of 117 that had arrived on February 4th were still being held at Bocanegra. ${ }^{161}$ It seems that those being kept at the estate were those who were less healthy, for on occasions sick slaves were sent back to the chácara from San Lázaro. Sick slaves were given blankets and barbacoas to sleep on.

Provisions were abundant on the central Peruvian coast, so providing food for the slaves while they were awaiting sale in Lima did not pose significant problems. ${ }^{162}$ Manuel Bautista Pérez's slaves were fed maize, wheat and meat, either beef or mutton, and were given

\footnotetext{
155 Bowser, African Slave, 67.

156 AGI Lima 44 Conde de Chinchón 24 Apr. 1633.

157 AGNL SO CO Ca 18 doc 197 p. 739 Accounts for 1618-1619 and Libro borrador, p. 69 Accounts for 1618-1619.

158 ANHS VM 77-II fol. 8 Joseph Núñez de Prado 8 Dec. 1634 and VM 77-I fol. 195 Solicitud para que visiten negros en Bocanegra... Manuel Bautista Pérez 14 Dec. 1634.

159 ANHS VM 77-I fol. 195v Doctor Juan de Vega 16 Dec. 1634.

160 AGNL SO CO Ca 20 doc 201 Gasto que se va haciendo con los negros que trajo Simón Váez en el navío Maestre Pedro de Burgos 1634.

161 AGNL SO CO Ca 20 doc 201 Acounts for 1633-1634.

162 Cobo, Obras, 2: 315.
} 


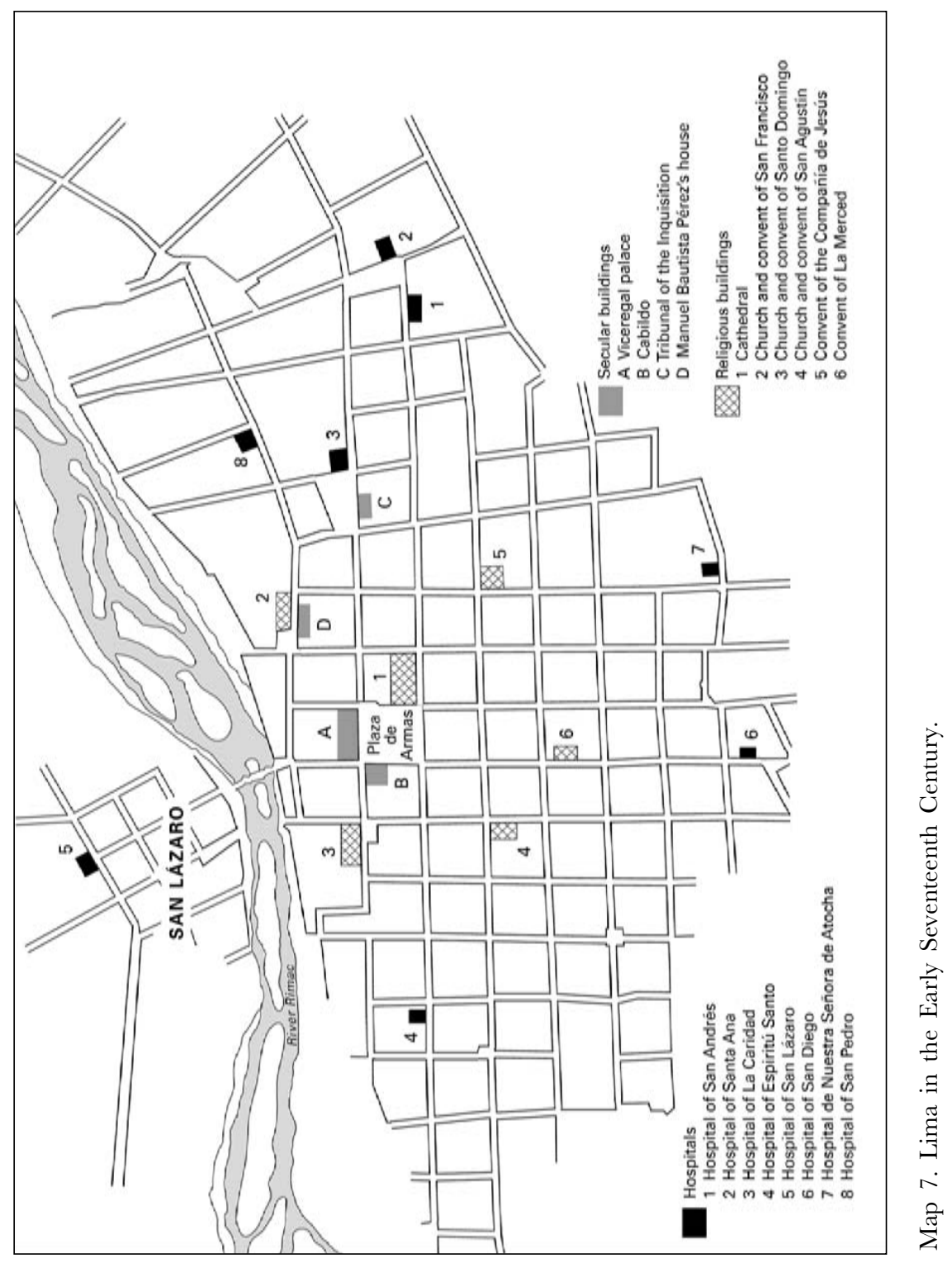




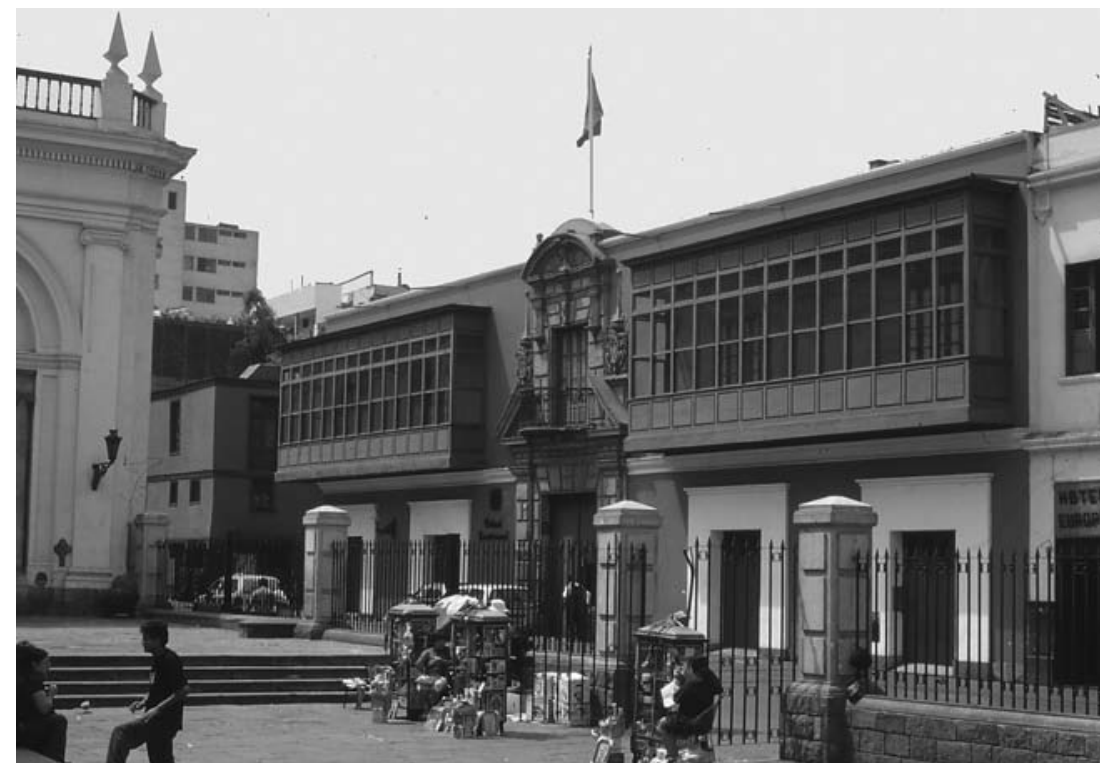

Figure 7. Manuel Bautista Pérez's House (Casa de Pilatos) in Lima Located Opposite the Church of San Francisco on Ancash Street (Author).

fish on Fridays and Saturdays. ${ }^{163}$ Occasionally they were also given honey, wine and tobacco. The accounts for 1632 indicate that expenditure on food accounted for approximately 14 percent of the total costs associated with slaves whilst they were in Lima, with maize and wheat accounting for about 53 and 47 percent of the total respectively. ${ }^{164}$ The accounts for this particular year include no other food items, but the following year fish, that included anchovies and shrimps, as well as beans and acemitas were purchased regularly. These foods are always included with other items and it seems likely that they were also purchased in 1632. However, it is possible that

163 ANHS VM 79 fols. 107, 108v. Expenses generated by slaves in Lima [1627]; AGNL SO CO Ca 20 doc 201 Accounts for 1632 and 1633. Similar rations of mutton, wheat, maize and beans were provided for slaves on the estate of Captain Lorenzo Pérez de Noguera (AGNL Real Audiencia. Causas civiles. Leg 103 cuaderno 38 fol. 562 Autos del concurso de acreedores formado a los bienes de D. Lorenzo Pérez Noguera 1637).

164 AGNL SO CO Ca 20 doc 201 Accounts for 1632. The proportion spent on food would have depended on a variety of factors, in particular how long it took to sell the slaves. 
the later arrival of the 1632 consignment, in April rather than February, may have meant that fish was less available. Fish was said to be abundant in Callao between November and April, but absent during the rest of the year when the garuas prevailed. ${ }^{165}$ At times when fresh fish was not available the slaves were probably fed dried or salt fish imported from the north coast. ${ }^{166}$

In Lima the slaves consumed large quantities of meat, mostly in the form of beef. From the 1540s livestock raising enterprises developed around the city to meet the growing demand for meat. ${ }^{167}$ Cattle dominated on the coast where the climate did not favour the raising of sheep, but both cattle and sheep were raised in the sierra and brought down to the coast for fattening. In order to ensure an adequate supply of meat for the city at low prices, the cabildo controlled its sale and the butchering of livestock, which was restricted to two public slaughterhouses, one on the other side of the River Rímac and the other next to the church of Santa Ana. According to Father Cobo over 600 carneros were killed daily at these abattoirs and 2,700 cattle slaughtered every year. ${ }^{168}$ Even though Lima was well supplied with meat, the limited availability of pasture meant that the cattle were often thin, such that they had to be fed alfalfa, which raised the price of meat. ${ }^{169}$ The slaves appear to have been fed significant amounts of meat. In 163436 slaves held at Pérez's chácara were being fed two and a half arrobas (62.5 pounds) of meat a day. Taking into account that the meat would probably have been purchased on the bone, ${ }^{170}$ this would have provided a daily ration of just under one pound a day. In the late sixteenth century the daily ration of slaves working in the hospital of Santa Ana in Lima was one and a half pounds of meat for male slaves and one pound of beef and mutton for female slaves, as well as three acemitas for men and two for women for lunch and dinner, while on fish days they were given

165 Lizárraga, Descripción breve, cap. 57: 42.

166 Cobo, Obras 2: 316; Glave, "Puerta del Perú", 517.

167 Keith, Conquest and Agrarian Change, 56-64.

168 Cobo, Obras 2: 316. In 1619 the raisers of carneros in the hinterland of Lima claimed that they were raising more than 160,000 carneros a year, which were drawn from 100 leagues around the city (AGI Lima 149 Memorial de los criadores de ganado ovejuno 1619).

169 AGI Lima 108 Cabildo de Lima 18 Jan. 1621.

170 As with the calculation of meat consumption in Cartagena, it is assumed that 40 percent of a carcass was bone, but it may have been higher. 
a fish broth. ${ }^{171}$ In Lima an arroba (25 pounds) of beef sold for about six reals, ${ }^{172}$ whilst carneros usually cost between ten and twelve reals and were generally sold in quarters of seven pounds each. ${ }^{173}$ This meant that mutton was about one third more expensive than beef, selling at one pound for 0.36 reals compared to 0.24 reals for beef. In the account books many entries just refer to "carne" or meat so that it is difficult to be precise about the proportions of beef and mutton that were purchased. However, where mutton is mentioned it seems to have been bought in much smaller quantities and to have been preferred for the sick; ${ }^{174}$ it may have been used as a substitute for fish on Fridays and Saturdays. ${ }^{175}$ On Jesuit haciendas slaves were fed primarily beef with lamb and jerky only given to them when this was not available. ${ }^{176}$ Entries for the purchase of firewood "para guisar" suggest that the beef may have been prepared as a stew.

Compared to beef and mutton, pork and chicken were less commonly fed to slaves. Although pigs were said to be very cheap, because of the lack of oil for cooking they were generally raised for their fat rather than for meat. ${ }^{177}$ Pork was occasionally fed to the sick, though not as extensively as in Cartagena. Chicken was rarely fed to slaves in Lima, despite being relatively cheap at between 2 and 4 reals each. ${ }^{178}$ The few that were purchased were for the sick. ${ }^{179}$ Indeed chicken coops were a common feature of hospitals in Lima. ${ }^{180}$ In 1606 the hospital of Santa Ana had a chicken coop containing

171 ABPL 9086 f.87 Ordenanzas para el hospital de Santa Ana 4 Dec. 1590. The basic rations did not differ in the amount of meat provided for administrators and slaves, but the former received 2 pounds of white bread and 2 pochuelas [pozuelas] of wine, as well as more vegetables and fruit.

${ }_{172}$ Descripción del Virreinato, 52; LC 19 61-617 Cabildo of Lima 2 Jun. 1623.

173 ANHS VM 79 fols. 107, 108v. Expenses generated by slaves [1627]; AGNP Real Audiencia. Causas civiles. Leg 103 cuaderno 38 fol.562 Autos del concurso de acreedores formado a los bienes de D. Lorenzo Pérez Noguera [1637].

174 See also Nicholas P. Cushner, Lords of the Land: Sugar, Wine and Jesuit Estates of Coastal Peru, 1600-1767 (Albany: SUNY Press 1980), 94.

175 AGNL SO CO Ca 20 doc 201 Accounts for 1633; Cobo, Obras 2: 316.

176 Cushner, Lords of the Land, 92.

177 Descripción del Virreinato, 52; Cobo, Obras 2: 316.

178 Descripción del Virreinato, 52.

179 AGNL SO CO Ca 18 doc 197 Accounts for 1618-1619 and Libro borrador, pp. 69-70 1618-1619.

180 AGI Lima 131 ff. $7 \mathrm{v}-8 \mathrm{v}$ Visita of the hospital of San Andrés by lic Alonso Maldonado de Torres 22.2.1588; ABPL 9086 fols. 65-92 Visita al Hospital de Santa Ana Ordenanzas para el hospital 4 Dec. 1590. 
100 chickens, but given that it consumed about 6,000 a year, this was regarded as insufficient and the inspectors ordered that another 1,000 should be purchased. ${ }^{181}$

The main cereals consumed by the slaves were maize and wheat. Slaves in Peru commonly ate maize and wheat in the form of gruel, known as sango, to which condiments might be added, but maize was also made into balls that were boiled. ${ }^{182}$ However, the account book suggests that the wheat and maize consumed by those lodged at both Bocanegra and San Lázaro was made into bread or acemitas made of bran. ${ }^{183}$ In 1633 weak slaves were being fed about one pound four ounces of bread a day, comprising rather more maize than bread (pan amasado). ${ }^{184}$ According to the hospital ordinances of Santa Ana in 1590, four fanegas of wheat could provide 90 loaves of white bread and 90 acemitas weighing one pound each. ${ }^{185}$ Being favoured by the Spanish and well suited to the climatic conditions of the region, the cultivation of wheat was encouraged by encomenderos and expanded rapidly on small estancias around Lima in the 1540s. ${ }^{186}$ Father Cobo claimed that yields of wheat reached as high as one to fifteen or thirty, which were double normal yields. ${ }^{187}$ In addition he claimed that as much as 150,000 fangeas each of wheat and maize were being imported from other coastal valleys from as far north as Santa and as far south as Pisco. ${ }^{188}$ As such by the early seventeenth century maize and wheat were said to command the same price of between ten and twelve reals a fanega. ${ }^{189}$ However, by the 1620 s and 1630 s the price of wheat had risen. Wheat producers attributed rising

181 ABPL 9806 fols. 47-48 Visita al hospital de Santa Ana 2 Oct.1606. See also ABPL 9806 fols. 71-72 Visita al hospital de Santa Ana Autos issued in Lima 27 Jul. 1587.

182 AGNL Real Audiencia Causas Civiles leg. 103 cuaderno 38 fols. 557-77 Cuenta que doy yo el Capitán Alonso Bravo de los aprovechamientos y gastos 1637; Descripción del Virreinato, 48-49; Cushner, Lords of the Land, 95.

183 AGNL SO CO Ca 20 doc 201Accounts for 1632 and 1633.

184 Manuel Bautista Pérez claimed he was feeding 140 weak slaves the same amount of food as 200 Upper Guinea slaves which was one fanega of pan amasado (probably wheat bread) in the morning and 1.5 fanegas of maize in the afternoon (ANHS VM 79-II fol. 12 Manuel Bautista Pérez to Sebastián Duarte 1 Jul. 1633).

185 ABPL 9086 fol. 94v Ordenanzas para el hospital de Santa Ana 4 Dec. 1590.

186 Keith, Conquest and Agrarian Change, 65-75.

187 Cobo, Obras 1: 408.

188 Cobo, Obras 2: 315.

189 Descripción del Virreinato, 53. 
prices to the decline in the native labour, the rising costs of slaves and oxen, attacks by pests and declining yields. ${ }^{190}$ As such in the 1630s wheat was selling at three pesos and maize between two and two and a half pesos a fanega. ${ }^{191}$

Agricultural production in the hinterland of Lima was diversified, such that many of those who grew wheat or maize also cultivated vegetables and fruit for the urban market. These crops included beans, melons, avocadoes, lucumas and plantains, as well as a range of European crops such as cabbages, aubergines, lettuces, endives, radishes and artichokes. ${ }^{192}$ Despite the abundance of vegetables and fruit in Lima, the only item listed in the accounts of food purchased for slaves was beans. It is possible that vegetables and fruit were so cheap that they did not merit inclusion in the accounts, though they are recorded for other stretches of the journey. It is also possible that some fruits were supplied from Manuel Bautista Pérez's estate at Bocanegra, where plantains, guavas, avocadoes, figs, oranges, lemons and other fruit trees were cultivated. ${ }^{193}$ However, it does not appear to have been common practice to provide vegetables and fruit for slaves in Lima. They were not included in rations for slaves working in hospitals, whereas they were for their administrators. ${ }^{194}$ The only other items purchased for the slaves were sugar, conserves and wine, which appear to have been only for the sick.

Manuel Bautista Pérez budgeted on the basis that a slave ration cost one real a day. ${ }^{195}$ This would seem to be generous compared to rations provided for slaves working in the hospital of Santa Ana,

\footnotetext{
190 AGI Lima 158 Los labradores de la ciudad de los reyes con el fiscal de su majestad 12 Oct. 1621.

191 AGNL SOCO Ca 20 doc 201 Accounts for 1632 and 1633.

192 López de Velasco, Geografia, 236; Vázquez de Espinosa, Compendio, 295; Cobo, Obras 2: 317; Carletti, Voyage, 42-43; Descripción del Virreinato, 44-48; Keith, Conquest and Agrarian Change, 66-72. The inventory of Manuel Bautista Pérez's estate of 100 fanegadas at Bocanegra reveals that apart from a large number of livestock, the estate produced maize, wheat, barley, olives, plantains and many fruits. It also employed thirty-one slaves (AGNL SO CO Ca 108 doc 848 El Fisco Real de este Santo Oficio 10 Oct. 1633).

193 AGNL SO CO Ca 108 doc 848 El Fisco Real de este Santo Oficio 10 Oct. 1633.

${ }_{194}$ ABPL 9086 fol. 73 Ordenanzas para el hospital de Santa Ana 4 Dec. 1590.

195 AGNL SO CO Ca. 18 doc 197 pp. 265-68 Accounts regarding 138.5 piezas taken to the Indies (1614-15).
} 
where it cost less than half a real a day. ${ }^{196}$ However, it was less than that provided for artisans, which was between one and a quarter and one and a half reals a day, but many of these would have been working in construction, such as in sawmills, carpentry or brick making, where their energy needs would have been greater. ${ }^{197}$ One real a day seems to have been fairly common in Lima, though rather less in rural areas where the slaves probably supplemented their rations from garden plots. ${ }^{198}$

\section{Slave Sales in Lima}

In most cases Manuel Bautista Pérez's consignments of slaves arrived in March or April and by the end of August generally 90 percent had been sold. ${ }^{199}$ Any remaining slaves were transported south to be sold in Pisco or Arica in October or November. While many of these remaining slaves were of poor quality, as will be shown below, there was also a good market for Angolan slaves in these regions. The time taken to dispose of the slaves would have varied with market conditions. On his disastrous venture in 1620 to 1621 when he lost 61 slaves to smallpox and measles in Panama and arrived in Lima after other slave traders, within the first two weeks he had only been able to sell 40 of the remaining 229 slaves. ${ }^{200}$ Most of the slaves were sold in ones and twos. For example, the sale of 208 slaves in 1619 involved 104 transactions. ${ }^{201}$ This reflected the high cost of the slaves. In the early seventeenth century corregidores were paid between 1,000 and 2,000 pesos ensayados and officials of the royal

196 ABPL 9086 f.87 Ordenanzas para el hospital de Santa Ana 4 Dec. 1590.

197 Emilio Harth-terré and Alberto Márquez Abanto, "Las bellas artes en el virreynato del Perú: el artesano negro en la arquitectura virreinal limeña," Revista del Archivo Nacional del Perú 25 (1961): 377.

198 Bowser, African Slave, 224-26.

199 AGNL SO CO Ca 20 doc 201 Slave sales 1623, 1625, 1626, 1629-1634 and AGNL SO CO Ca 25 doc 251 Slave sales 1626. For example, in 1619 he arrived in Lima with 208 slaves on March 21 and by August he had sold 181 slaves, while 9 had died (AGNL SO CO Ca 2 doc 8 Venta e rendimento de duzemtas e vimte e sete peças de escravos 1620 ).

${ }^{200}$ AGNL SO CO Ca 18 doc 197 Libro borrador, Manuel Bautista Pérez to Felipe Rodríguez 28 Apr. 1621.

${ }^{201}$ AGNL SO CO Ca 2 doc 8 Venta e rendimento de duzemtas e vimte e sete peças de escravos 1620. 
exchequer less than 1,000 pesos ${ }^{202}$ so that slaves costing between 550 and 600 pesos represented a significant proportion of an individual's annual salary or income. Nevertheless, given that a skilled slave could be hired out at fourteen reals a day and that food cost between one and a quarter and one and a half reals a day, investment in a slave worth 600 pesos could be recovered in about fifteen months, though this did not take account of other expenses such as clothing or medical care. ${ }^{203}$ In fact it was said that a poor widow or orphan could live off the labour of only one slave. ${ }^{204}$

Due to the high price of slaves most purchasers could not afford to buy them in a single cash transaction, even though slave traders preferred this method of payment since they needed the ready money to pay their investors and suppliers and also to purchase further slaves in Cartagena the following year. Manuel Bautista Pérez aimed to remit his silver to associates in Panama and Cartagena under the protection of the Armada del Mar del Sur that left Callao for Panama in May. ${ }^{205}$ However, from the earliest years of his involvement in the slave trade Pérez was forced to offer various forms of credit. ${ }^{206}$ Typically only a few slaves would be bought for cash; most were purchased on credit in the form of an initial down payment, normally about half of the purchase price, with the rest payable the following year, or occasionally over two years. On rare occasions monthly payments might be agreed. Hence in 1619 out of a total expected income of 122,175 pesos from the sale of slaves, he initially received only 46.8 percent in cash, with the rest payable the following year. ${ }^{207}$ In later years the proportion paid up front in cash tended to decline, although it was highly variable, ${ }^{208}$ and by the 1630 s some slaves were sold entirely on credit and on occasions repayments were made in

\footnotetext{
${ }^{202}$ Vázquez de Espinosa, Compendio, 505-507. The salaries of oidores, alcaldes and fiscales were only 3,000 ducados.

${ }^{203}$ This is a recalculation of Bowser's estimate using an average slave price of 600 pesos (African Slave, 138).

${ }^{204}$ AGI Santa Fe 40 R 3 N51 doc 1 Melchor de Aguilera 24 Aug. 1639.

205 Clayton, "Trade and Navigation," 2.

${ }^{206}$ For a discussion of the complex credit transactions involved in the sale of slaves see Minchin, "May You Always Care for those of Your Patria"" 72-77; Bowser, African Slave, 70.

207 AGNL SO CO Ca 2 doc 8 Venta e rendimento de duzemtas e vimte e sete peças de escravos 1619-1620.

${ }^{208}$ Minchin, "May You Always Care for those of Your Patria'," 73.
} 
the form of commodities such as wheat, barley or maize. ${ }^{209}$ Although most of the purchases were on credit, few failed to make the repayments. Getting the balance between income and expenditure, when many transactions were based on credit and when there were investors and numerous suppliers to be paid at different points in the trade, required considerable planning and business skill. Manuel Bautista Pérez earned the reputation of being a trusted supplier of good quality slaves and a reliable source of credit, so that his business thrived while disasters and the lack of access to credit claimed the enterprises of less astute merchants. ${ }^{210}$

In Lima slaves were not generally acquired for large agricultural or mining enterprises, but rather for domestic service and for employment as skilled assistants or artisans. That said, those purchased in larger lots were generally for agricultural labour. From the outset Manuel Bautista Pérez aimed to operate at the top end of the market. Even though he was new to the slave trade, his clients in 1619 included a lawyer to the Audiencia, a treasury official, several priests and a musician attached to the cathedral. However, most were artisans, including a silversmith, tailor, hat maker, saddler, rope maker and several cake makers, as well as a pharmacist and a number of shopkeepers and small holders. ${ }^{211}$ The range of occupations of Pérez's clients continued in later years. Perhaps he understood that when a fixed transport cost is applied to two similar goods the effect is to make the better quality good less expensive. ${ }^{212}$

There is considerable evidence for the sale of slaves by Manuel Bautista Pérez in Lima. It is difficult to tie all the sales in any one year to a specific consignment, since it might take several years to sell all the slaves and small numbers were sometimes returned as unsatisfactory to be resold at a later date. However, since most slaves were sold within a short time of arrival in Lima, the prices of slaves given in Table 6.5 are largely comparable, though not totally, with those in Table 5.1 which gives their purchase price in Cartagena.

209 AGNL SO CO Ca 20 doc 201 Slave sales 1633.

210 Minchin, "May You Always Care for those of Your Patria'," 59-60. Minchin (pp. 98-107) provides details on the less successful slave trading ventures of Jorge de Silva and Juan Rodríguez de Silva.

211 AGNL SO CO Ca 18 doc 197 Libro borrador Ventas de esclavos 1619-1620.

212 Jonathan B. Pritchett and Richard M. Chamberlain, "Selection in the Market for Slaves: New Orleans, 1830-1860," Quarterly Fournal of Economics 108 (2)(1993): 466. 
Table 6.5. Average Prices of Slaves Sold in Lima, Pisco and Arica 1619 to 1634

\begin{tabular}{|c|c|c|c|c|c|c|c|c|c|c|c|}
\hline & 1619 & 1621 & 1623 & 1625 & 1626 & 1629 & 1630 & 1631 & 1632 & 1633 & 1634 \\
\hline Angola females & & 587 & 603 & 521 & 535 & & 546 & 580 & 567 & 579 & 588 \\
\hline Angola males & & 595 & 616 & 546 & 549 & & 547 & 583 & 587 & 595 & 606 \\
\hline $\begin{array}{l}\text { females } \\
\text { Upper Guinea }\end{array}$ & 666 & 584 & 602 & 546 & 556 & 556 & 601 & 573 & 589 & 581 & 627 \\
\hline $\begin{array}{l}\text { males } \\
\text { Gold Coast }\end{array}$ & 643 & 610 & 613 & 586 & 594 & 576 & 600 & 603 & 611 & 608 & 626 \\
\hline $\begin{array}{l}\text { females } \\
\text { Gold Coast } \\
\text { males }\end{array}$ & & 601 & 603 & 616 & 598 & & & & & & \\
\hline $\begin{array}{l}\text { Total number } \\
\text { of observations }\end{array}$ & 134 & 212 & 74 & 369 & 255 & 107 & 51 & 39 & 313 & 183 & 261 \\
\hline Average price & 649 & 604 & 612 & 567 & 563 & 568 & 584 & 588 & 591 & 593 & 615 \\
\hline
\end{tabular}

Sources: AGNL SO CO Ca 2 doc 8 Venta e rendimento de duzemtas e vimte e sete peças de escravos 1619-1620; AGNL SO CO Ca 20 doc 201 Slave sales 1623, 1625, 1626, 1629-1634; AGNL SO CO Ca 18 doc 197 Libro borrador - Slave sales 1621-22 and AGNL SO CO Ca 25 doc 251 Slave sales 1626.

Includes only adult slaves and those whose ethnic origin is known. Prices are in pesos.

The price of slaves depended on the quality and particular attributes of the slaves, but it was also affected by market conditions. Ablebodied slaves in their late teens and early twenties commanded the highest prices. Female slaves were generally about 10 to 20 pesos cheaper than male slaves with the difference in the price of male and female slaves being higher for those from Upper Guinea, while youths generally cost about 100 to 150 pesos less than adults. ${ }^{213}$ Those with defects such as missing teeth, cloudy lenses, hernias or sores sold for slightly less and were generally the last to be sold. On the other hand particularly attractive slaves and those with special skills or a suitable temperament might command higher prices. The average price for Manuel Bautista Pérez's slaves in Lima ranged

213 This differential is considerably lower than in Brazil and North America where the value of female slaves was only 70-80 percent and 80-90 percent of the value of a male slave respectively. It is even less than that found in parts of Spanish America, which was about 90 percent (Carlos Newland and María Jesús San Segundo, "Human Capital and Other Determinants of the Price Life Cycle of a Slave: Peru and La Plata in the Eighteenth Century," The Fournal of Economic History 56 (3) (1996): 699. 
between about 570 and 600 pesos (Table 6.5). In Cartagena slaves from Upper Guinea cost 40 to 50 pesos more than Angola slaves, but the sale prices in Lima did not exhibit such a consistently high differential. Upper Guinea slaves were generally more expensive, but the difference in price varied considerably from year to year.

Sick or weak slaves from Upper Guinea were generally the last to be sold and, together with some Angola slaves, were shipped out of Lima for sale in Pisco, Arica, or Moquegua. Some were taken by a brother-in-law, either García Váez Enríquez or Simón Váez Enríquez, who also collected debts, ${ }^{214}$ but Pérez also had an agent, Manuel de Acosta, based in Arica. Simón Váez Enríquez first undertook this task in 1628 when he received detailed instructions from Pérez about the transport and sale of fifty slaves. Of these slaves he was to sell only a few in Pisco, because it was said that greater profits could be made in Arica. He was also instructed to be open about any physical defects the slaves might have, otherwise they would be returned. For provisions he was to acquire maize, some fish and meat, and other foods, as well as water, making sure that he spent as little as possible, and also see that the slaves did not travel in the sun or were given food or other things that might harm them. ${ }^{215}$ It seems that the slaves travelled overland to Pisco and then by sea to Arica.

Despite the additional costs of transport and maintenance prior to sale, which might mount to about 25 to 40 pesos a slave, those shipped to southern regions were not always more expensive. ${ }^{216}$ In 1625 the average price of forty-four slaves sold in Pisco, Arica and the Sama Valley, excluding three youths, was 540 pesos, which may be compared to an average price in Lima at the time of 567 pesos. $^{217}$ However, the average price varied with the place of sale and with the ethnic origin of the slaves. Slaves of whatever origin were consistently more expensive in Pisco than in Lima, with the difference in price exceeding the additional costs of transport. Here Angolan slaves were comparable if not more expensive than slaves from Upper

${ }^{214}$ AGNL SO CO Siglo XVII leg. 21 Manuel Bautista Pérez to Sebastián Duarte 2 Sep. 1628. In 1628 he was sending 65 slaves to Arica.

${ }_{215}$ AGNL SO CO Ca 2 doc 8 Libro borrador Manuel Bautista Pérez 16 Sep. 1628.

216 AGNL SO CO Ca 25 doc 251 Accounts for 1625-1627.

${ }^{217}$ AGNL SO CO Ca 20 doc 201 Venta de las pieças que llevó Sebastián Duarte de mi quenta a Pisco y a Arica [1626]. 
Table 6.6. Average Prices for Slaves Sold in Lima and Southern Peru 1625 to 1626

\begin{tabular}{lcccccc}
\hline & $\begin{array}{c}\text { Average } \\
\text { price } \\
1626\end{array}$ & $\begin{array}{c}\text { Price in } \\
\text { Lima } \\
1626\end{array}$ & $\begin{array}{c}\text { Price in } \\
\text { Pisco and } \\
\text { Chincha } \\
1626\end{array}$ & $\begin{array}{c}\text { Price in } \\
\text { Arica and } \\
\text { Moquegua } \\
1626\end{array}$ & $\begin{array}{c}\text { Price in } \\
\text { Pisco } \\
1625\end{array}$ & $\begin{array}{c}\text { Price in } \\
\text { Arica } \\
1625\end{array}$ \\
\hline $\begin{array}{l}\text { Angola females } \\
\begin{array}{l}\text { Angola males } \\
\text { Upper Guinea }\end{array}\end{array}$ & $535(39)$ & $526(34)$ & $594(5)$ & - & $578(2)$ & $540(2)$ \\
females & $556(37)$ & $562(33)$ & $600(1)$ & $493(3)$ & - & $570(1)$ \\
$\begin{array}{c}\text { Upper Guinea } \\
\text { males }\end{array}$ & $594(77)$ & $599(68)$ & $616(5)$ & $479(4)$ & $618(2)$ & $557(8)$ \\
\hline
\end{tabular}

Sources: AGNL SO CO Ca 20 doc 201 Venta de las piezas que llevó Sebastián Duarte 1626; AGNL SO CO Ca 25 doc 251 Slave sales 1626.

The table only includes adult slaves and those whose ethnic origin is known. Prices are in pesos and the numbers sold are given in parentheses.

Guinea (Table 6.6). This probably reflected two things: the tasks in which they were to be employed and the quality of the slaves. First, it probably indicated the general preference for Angolan slaves for agricultural labour. ${ }^{218}$ Although only fragmentary information is available for the occupation of buyers, several were chacareros, who probably employed them in the cultivation of vines, sugar and cereals. ${ }^{219}$ On the other hand the lower price for Upper Guinea slaves seems to have reflected their poor quality. In 1625 the average price for Angolas sold outside Lima was 563 pesos, for those from Upper Guinea 525 pesos and for those from the Gold Coast-Ardas and Caravalís - 516 pesos. Seven of these forty-four slaves had physical defects, such as missing fingers or toes, a hernia or ringworm (tiña), and two were in their thirties and all were associated with Upper Guinea slaves. However, there was a difference in prices in Pisco and Arica. Contrary to the advice given to Simón Váez Enríquez on this occasion slaves commanded much lower prices in Arica despite

${ }^{218}$ Tardieu, "Origin of the Slaves," 45-46, 53. Such a preference is suggested in a commission from a client, Jorge López de Paz in Arequipa, for the purchase of Angolas "strong for agricultural labour" (AGNL SO CO Siglo XVII Leg. 21 Jorge López de Paz to Manuel Bautista Pérez 15 Feb. 1634).

${ }_{219}$ Vázquez de Espinosa, Compendio, 325-26, 345-50. 
the additional costs of transport costs. ${ }^{220}$ Here at the end of the line the slave traders would have been anxious to dispose of the small number of remaining slaves at whatever cost.

Apart from the qualities of the slaves, their price was also affected by a large range of factors, many of which were out of the hands of the slave traders. The price of slaves might depend on their cost in Africa, the supply and demand for slaves in Cartagena and the mortality experienced by other operators on the journey to Peru. Frederick Bowser suggests that in the early seventeenth century between 1,000 and 1,500 African slaves were arriving annually at Callao, ${ }^{221}$ and it was generally thought that most slave traders would do well if the total number did not exceed 1,000 a year. ${ }^{222}$ With each slave trading ship carrying several hundred slaves, the loss of a single ship or part of a consignment through disease could significantly affect the availability and hence price of slaves. But, the price also depended on demand that might be affected by depressions in mining or agriculture and the availability of silver. The prices that Pérez obtained for his slaves generally support Frederick Bowser's assertion that the highest prices prevailed in the late $1610 \mathrm{~s}$ and early 1620 s, showing a decline towards the end of the $1630 \mathrm{~s},{ }^{223}$ though Manuel Bautista Pérez's slaves were consistently more expensive than most and his prices do not reveal such a sharp decline in the 1630s. While this trend probably reflected the availability of slaves, monopolistic practices may have contributed to the particularly high prices for slaves during the first two decades of the seventeenth century, when the cabildo complained that three suppliers were working together to maintain prices as high as 700 to 800 pesos. ${ }^{224}$

Comparing the average sale prices for slaves in Lima with purchase prices in Cartagena, and taking into account transport and maintenance costs on the journey, profits on individual slaves appear to have ranged quite widely from 44 to 77 percent (Table 6.7). ${ }^{225}$

${ }^{220}$ ANHS VM 77-II fols. 138-139 Venta de los negros . . . en Arica 1627. Excluding youths, in this year the average price of Angolas was 579 pesos and for Upper Guinea slaves 573 pesos. Five had missing teeth, one a hernia, one was deaf and had a broken arm, and one was blind in one eye.

221 Bowser, African Slave, 74-78.

222 Minchin, "May You Always Care for those of Your Patria'," 89.

223 Bowser, African Slave, 342-45.

224 LG 18: 794 Cabildo of Lima 17 Feb. 1620; Bowser, African Slave, 71.

225 These calculations do not include the extra transport and maintenance costs in Lima or on the journey south. 
Table 6.7. Profits on Individual Slaves Sold in Lima 1628 to 1634

\begin{tabular}{|c|c|c|c|c|c|c|c|}
\hline Year of purchase & 1618 & 1628 & 1629 & 1630 & 1631 & 1632 & 1633 \\
\hline Year of sale & 1619 & 1629 & 1630 & 1631 & 1632 & 1633 & 1634 \\
\hline $\begin{array}{l}\text { Purchase price of Angolan } \\
\text { slaves }\end{array}$ & & 230 & 272 & 305 & 276 & 305 & 283 \\
\hline $\begin{array}{l}\text { Sale price of Angolan } \\
\text { slaves }\end{array}$ & & $\mathrm{N} / \mathrm{A}$ & 546 & 582 & 581 & 591 & 602 \\
\hline $\begin{array}{l}\text { Percentage difference } \\
\text { Purchase price of Upper }\end{array}$ & & $\mathcal{N} / A$ & 100.7 & 90.8 & 110.5 & 93.8 & 112.7 \\
\hline $\begin{array}{l}\text { Guinea slaves } \\
\text { Sale price of Upper }\end{array}$ & 316 & 283 & 311 & 355 & 335 & 360 & 305 \\
\hline Guinea slaves & 649 & 568 & 600 & 596 & 608 & 600 & 626 \\
\hline Percentage difference & 105.4 & 100.7 & 92.9 & 67.9 & 81.5 & 66.7 & 105.2 \\
\hline $\begin{array}{l}\text { Expenses (transport, food, } \\
\text { medical care, taxes, etc.) }\end{array}$ & 56.75 & 56.75 & 56.75 & 56.75 & 56.75 & 56.75 & 56.75 \\
\hline Profit on Angolan slaves ${ }^{1}$ & & $\mathrm{~N} / \mathrm{A}$ & 66.1 & 60.9 & 74.6 & 63.4 & 77.2 \\
\hline $\begin{array}{l}\text { Profit on Upper Guinea } \\
\text { slaves }^{1}\end{array}$ & 74.1 & 67.2 & 63.2 & 44.7 & 55.2 & 44.0 & 73.0 \\
\hline $\begin{array}{l}\text { Profit on Angolan slaves } \\
\text { assuming } 10 \text { percent } \\
\text { mortality } \\
\text { Profit on Upper Guinea } \\
\text { slaves assuming }\end{array}$ & & $\mathrm{N} / \mathrm{A}$ & 49.5 & 44.8 & 57.1 & 47.0 & 59.5 \\
\hline 10 percent mortality ${ }^{2}$ & 56.7 & 50.5 & 46.8 & 30.3 & 39.7 & 29.6 & 55.7 \\
\hline
\end{tabular}

Sources: AGNL SO CO Ca 18 doc 197 pp. 715-18, 725-32, 735-40 Upper Guinea accounts 1613-1618; AGNL SO CO Ca 2 doc 8 Venta e rendimento de duzemtas e vimte e sete peças de escravos 1619-1620; AGNL SO CO Ca 20 doc 201 Slave sales 1629-1634; AGNL SO CO Ca 20 doc 201, ANHS VM 77-II fols. 56-58, 155-156v, 158, 267v, VM 79 fols. 116, 141-141v, 153-153v, 161, VM 79 II fols. 314v, 319.

Includes only adult slaves and those whose ethnic origin is known. Prices are in pesos.

${ }^{1}$ Profit is based on calculations for an individual slave and does not take account of mortality. It also excludes costs incurred in Lima.

${ }^{2}$ Calculated on the basis of a shipment of 300 slaves.

An unexpected finding is that Angolan slaves seem to have generated higher profits. This is opposite of that found on the Atlantic sector of the trade where slaves from Upper Guinea were more profitable. This reverse position would seem to derive from the greater availability and hence relatively lower prices for Angolan slaves in Cartagena and the sustained high demand for slaves of any kind in Peru. This is suggested by the fact that the purchase price for the slaves from the two regions differed by about 40 to 50 pesos, but the difference in sale price in Lima was considerably less. However, these estimated profits are based on the costs of landing a single 
Table 6.8. Profits on Annual Shipments from Cartagena in 1625,1626 and 1631

\begin{tabular}{lccc}
\hline $\begin{array}{l}\text { Year accounts drawn up (slaves would } \\
\quad \text { have been acquired in the previous year) }\end{array}$ & 1625 & 1626 & 1631 \\
Price of slaves (pesos) & 52,572 & 114,118 & 49,889 \\
Number of slaves purchased & 166 & 411 & 153 \\
$\begin{array}{l}\text { Death toll to date (no.) } \\
\text { Expenses from Panama or Cartagena to }\end{array}$ & 8 & 88 & 6 \\
$\quad$ Callao (pesos) & 8,925 & 18,444 & 8,866 \\
Expenses in Lima (pesos) & 2,957 & 8,168 & 3,511 \\
Expenses of slaves shipped for sale outside & & & \\
$\quad$ of Lima (pesos) & 909 & 2,791 & N/A \\
Total expenses (pesos) & 65,363 & 143,521 & 62,266 \\
Realised to date (pesos) & 23,282 & Included above & 55,817 \\
Accounts receivable (pesos) & 63,360 & Included above & 27,820 \\
Expected income (pesos) on slaves sold & 86,642 & 170,527 & 83,637 \\
& $($ from 153 & $($ from 310 & $($ from 143 \\
& slaves) & slaves) & slaves) \\
Slaves unsold when accounts drawn up & 13 & 13 & 10 \\
Net profit (pesos) & 21,279 & 27,006 & 21,371 \\
Percentage profit & 32.6 & 18.8 & 34.3 \\
Net profit margin (percent) & 24.5 & 15.8 & 25.5 \\
\hline
\end{tabular}

Sources: AGNL SO CO Ca 25 doc 251 and AGNL SO CO Ca 20 doc 201.

Note: Since a number of slaves still had to be sold, the final profit is likely to have been higher. The average cost of slaves differs from that shown in Table 6.6 because of the inclusion of children and slaves from different ethnic backgrounds.

slave in Lima and do not take account of mortality on the journey. A mortality of 10 percent on a cargo of 300 slaves might reduce the profits by between 14 and 18 percent. In addition to this, these estimated profits do not take into account the costs of maintenance in Lima, which could extend over several months, or the expenses involved in shipping the remaining slaves to southern Peru, which as indicated above might cost between 25 and 40 pesos. Neither do the figures take into account slave mortality in Lima, which in many years accounted for over half of the deaths experienced in any one consignment. The evidence from three annual shipments suggests that when the accounts were closed, the percentage profit was between 19 and 34 percent (Table 6.8). ${ }^{226}$ In fact the profits would have been

${ }^{226}$ Frederick Bowser (African Slave, 70, 372) includes similar tables for 1630 and 1631. The figures he includes for 1630 are correctly transcribed from the documentary source, but there is clearly an error in the document since other sources 
higher than this because not all the slaves had been sold at the time the accounts were drawn up. Reduced levels of profit appear to have been linked to high levels of mortality rather than to differences between the sale and purchase prices, while profits could be maintained by shipping larger numbers of slaves. In monetary terms the profit on a single consignment in the late 1620s was only about half of the 40,000 pesos profit he claimed to have made on his African venture in 1618 to 1619 when exceptionally high prices prevailed in Lima. ${ }^{227}$ In fact the profit from his early ventures may have enabled him to establish his business in Lima. Even though profits may have been lower in the following two decades, comparisons with the profits made on the Atlantic sector of the trade indicate that Manuel Pérez had made a wise decision to focus his business interests in the Americas.

(see Table 5.1) suggest that the slaves purchased in Cartagena would not have cost 390 pesos. Most likely the number of slaves purchased is underestimated. The table for 1631 differs slightly from Bowser's since it includes information on the sale of additional sales in Lima, which has been obtained from another document in the same legajo.

${ }^{227}$ AGNL SO CO Ca 18 doc 197 Manuel Bautista Pérez to Diego Rodríguez de Lisboa 12 Jul. 1620. 